\title{
Operation Varsity Blues and the NCAA's Special Admission Exception
}

\begin{abstract}
Joshua Lens
"Operation Varsity Blues," the university admissions scandal and ensuing federal investigation, made national news and captivated the public. Fascination with the scandal could have stemmed from the involvement of celebrities such as Lori Loughlin and Felicity Huffman and/or the sheer ridiculousness of the scheme, in which wealthy and prominent families paid exorbitant amounts of money to secure their childrens' admission to elite universities. Others may have closely followed the resulting legal proceedings that included federal criminal charges like racketeering against 50 individuals and civil lawsuits against elite universities and celebrities with one suit seeking $\$ 500$ billion in damages. Lawmakers' attempts at preventing future university admissions scandals legislatively may have also caused curiosity.

This article, though, explores the scandal's intricate ties to college athletics and seeks to determine the most effective and practical means to mitigate the likelihood of a future similar admissions scandal. More specifically, the article explores how head coaches and an athletics administrator used their positions at academically elite universities to exploit a little-known NCAA rule permitting universities to use more lenient admissions standards for incoming student-athletes. Scheme participants falsely indicated dozens of applicants were incoming student-athletes in order to trigger the less rigorous standards and secure admission to elite universities. The criminal proceedings resulting from the scandal have yielded relatively light sentences for involved coaches, and civil suits against universities have been unsuccessful. California attempted to address the scandal legislatively, but, as this article explains, its reform package contains holes that fail to address many of the scheme's key components.

The article concludes that the NCAA, as opposed to lawmakers, the legal system, or individual universities, is in the best position to prevent, or mitigate the likelihood of, a future university admissions scheme like Operation Varsity Blues. Doing so would require only eliminating a single NCAA rule that is inconsistent with myriad other NCAA rules and principles and has resulted in decades of poor academic results.
\end{abstract}

Keywords: NCAA, university admissions, college athletics, Operation Varsity Blues

Joshua Lens, JD, is an assistant professor in the College of Education and Health Professions at the University of Arkansas. Prior to entering academia, he spent seven years on Baylor University's athletics compliance staff and, in addition to his duties at the University of Arkansas, consults for college athletics conferences, universities, and university athletics departments regarding legal and NCAA matters. Email: lens@uark.edu 


\section{Introduction}

A bright, well-rounded high school senior from a middle-class family applies to many academically prestigious universities such as Yale, Stanford, Georgetown, the University of Texas, the University of California, Los Angeles ("UCLA"), and the University of Southern California. A multi-sport, star athlete, she considered continuing her athletics career at the university level but ultimately decided to notify the college coaches who recruited her that she would not play a sport in college and instead focus on academics.

The applicant eagerly checks her e-mail frequently for notification of university admissions decisions, reasonably believing her sterling grades and standardized test score, along with her contributions to the community, should get her admitted to at least one of the universities to which she applied. Instead, she learns of a university admissions scandal that includes many of the universities to which she applied. As she reads about it, she realizes that the scandal could directly impact her ability to secure admission to these universities. As part of the scandal, less qualified applicants and their families utilized their wealth and university coaches to exploit a little-known NCAA rule and process to obtain admission to elite universities through a side door. And every admissions slot filled by these less qualified applicants is one less available to her.

While she is secretly pleased to learn that the involved parents, coaches, and other parties face federal criminal prosecution, the applicant and her family are left to wonder how this could happen. Also, could something similar happen to the applicant's younger sister when she applies to universities in a couple of years? Further, what recourse, if any, is available for the student against any university that denies her admission application but was involved in the scandal and admitted less qualified and dishonest applicants through the side door?

The news was absurd but somehow predictable, hilarious nonetheless somber-perhaps yet a logical development in university admissions. ${ }^{1}$ In March 2019, FBI agents raided several wealthy and prominent families' multi-million dollar homes, sometimes entering with guns drawn. ${ }^{2}$ In culmination of an investigation they dubbed "Operation Varsity Blues," federal agents arrested dozens

\footnotetext{
1 See Andy Thomason, Nell Gluckman, \& Lindsay Ellis, One Year After College-Admissions Scandal, 3 Questions About What (if Anything) Has Changed, The Chronicle of Higher EducATION (Mar. 12, 2020), http://chronicle.com/article/One-Year-After/248235 (detailing the scandal's effects on nationwide university admissions).

2 See Joey Garrison, A Year Later, Prosecutors Are Winning Historic College Admissions Case, But Fight Isn't Over, USA Today (Mar. 11, 2020), http:/usatoday.com/story/news/education/2020/03/11/lori-loughlin-felicity-huffman-college-admissions-scandal-prison/4928136002/ (examining Operation Varsity Blues fallout a year after news of it broke).
} 
of individuals for their involvement in a nationwide scheme that facilitated applicants' admission to elite academic universities through cheating on standardized college entrance exams and as purported prospective student-athletes. ${ }^{3}$

Likely instant responses to news of the scandal included disbelief at the large bribe amounts, shock at the use of Photoshop to create fake athletics credentials and profiles for applicants, and the inclusion of both Aunt Becky from Full House (actress Lori Loughlin) and Desperate Housewives actress Felicity Huffman. ${ }^{4}$ Operation Varsity Blues revealed the staggering lengths to which some parents will go - or fall — to assist their children in securing admission to academically elite universities. ${ }^{5}$ The episode frustrated many who had not appreciated that a different set of university admissions standards applies to the wealthy. ${ }^{6}$ Yet the scandal entertained others who followed along curiously as federal authorities indicted affluent and prominent individuals for felonies. ${ }^{7}$ Lifetime even produced a movie about the scheme. ${ }^{8}$

According to current University of Oklahoma professor and former college athletics administrator Gerald Gurney, the takeaway from Operation Varsity Blues is not the celebrity tie to university admissions but rather the involvement of university athletics departments and employees. ${ }^{9}$ Gurney suggests, "What

\footnotetext{
3 See Dep't of Just., U.S. Attorney's Office, District of Massachusetts Release, Investigations of College Admissions and Testing Bribery Scheme, U.S. DePT' of Just. (Mar. 12, 2019), http://jus-

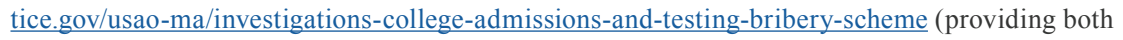
information on involved parties and relevant court documents).

4 See Thomason, supra note 1 (describing likely instant reactions to Operation Varsity Blues).

5 See Paul Rosen, Varsity Blues: How Universities Can Protect Themselves in the Wake of the Admissions Scandal, Forbes (Mar. 19, 2019), http://forbes.com/sites/paulrosen/2019/03/19/varsityblues-how-universities-can-protect-themselves-in-the-wake-of-the-admissions-scandal/\#6e $98 \mathrm{e}-$ $2185 \mathrm{a} 9 \mathrm{~b}$ (providing recommendations to universities to help mitigate the likelihood of applicants circumventing normal admissions process). The FBI dubbed the federal investigation into university admissions as "Operation Varsity Blues." See Scott Jaschik, Massive Admissions Scandal, InSIDE Higher Ed (Mar. 13, 2019), http://insidehighered.com/admissions/article/2019/03/13/dozens-indicted-alleged-massive-case-admissions-fraud (detailing Varsity Blues).

${ }_{6}$ See Ian Bogost, What the Scammers Got Right About College Admissions, The Atlantic (Mar. 21, 2019), http://theatlantic.com/education/archive/2019/03/real-college-bribery-scandal-whats-legal/585298/ (analyzing university admissions shortcomings).

7 See id. (detailing the public's reactions to scheme).

8 See Garrison, supra note 2 (describing the scandal as so "juicy" that it became the subject of a movie, book, and podcasts).

9 See Nick Anderson \& Susan Svrluga, Bribery Scandal Points to the Athletic Factor: A Major Force in College Admissions, The Washington Post (June 13, 2019), http://mercurynews. com/2019/06/13/scandal-reveals-side-door-to-top-schools-athletics/ (describing the role of university athletics departments in circumventing admissions standards). Loughlin and Huffman are the household names associated with the scandal, but the scheme includes several national leaders in business, law, and other fields. See Jaschik, supra note 5.
} 
they ought to be talking about ... is why is higher education giving authority to an athletic department? Why do they do that? It's antithetical to the mission of the university." ${ }^{\prime 10}$

College athletics entered the Operation Varsity Blues scheme when wealthy parents, such as Loughlin, paid outrageous money and at times used fake athletics credentials to assist their children in obtaining admission to academically selective universities through a "side door." ${ }^{\text {"11 }}$ Little-known NCAA legislation permitting its member universities to provide relief from their own stated admission requirements for incoming student-athlete applicants created the side door. The involved parties slipped through it by conjuring up applicants' sterling athletics credentials in mostly niche sports such as rowing so athletics participation could trigger less rigorous admission standards and serve as the avenue into top universities. ${ }^{12}$ College coaches of numerous other sports also participated. ${ }^{13}$ The federal investigation implicated coaches at the University of Southern California, Stanford University, Yale University, Wake Forest University, and Georgetown University, among others. ${ }^{14}$

Rick Singer, a college admissions consultant and scheme mastermind, described the side door admission deal he offered clients as a quid pro quo, under which parents made purported donations to one of Singer's entities in exchange for his assistance in securing their children's admission to elite universities. ${ }^{15}$ Singer funneled those payments to select college coaches or their athletics programs' accounts. ${ }^{16}$ In exchange, these coaches used their clout with their

\footnotetext{
10 See Anderson \& Svrluga, supra note 9.

11 See id. The "side door" metaphor originated with scheme mastermind Rick Singer's description of the enterprise. See Thomason, supra note 1 (describing scheme as "easy to understand" due to the metaphor). In court, Singer admitted that he "... created a side door that would guarantee families would get in." See Janice Williams, Who Is Rick Singer? The Key CEO Helped Lori Loughlin, Felicity Huffman Daughters and Plenty More Wealthy Scam Their Way Into College, Newsweek (April 3, 2019), http://newsweek.com/rick-singer-college-admissions-scam-1384647 (profiling Singer). Instead of assisting families gain university admission through the visible, traditional, and most commonly used front door, Singer pitched guaranteed admission to his clients through a side door that was more discreet and accessible only to major donors and other important people. See Janice Nadler, Ordinary People and the Rationalization of Wrongdoing, 118 Мich. L. Rev. 1205, 1221 (Apr. 2020) (explaining that Singer preyed on upper-class families' anxieties). It is not ironic that Singer's consulting company's name was The Key.

12 See Anderson, supra note 9.

13 See id.

14 See Dep't of Justice, supra note 3. These universities' athletics programs participate at the NCAA's highest level, Division I. See Dept' of Justice, Affidavit in Support of Criminal Complaint 『| 19, U.S. Dept' of Just. (Mar. 11, 2019), located at http://justice.gov/file/1142876/download (last visited July 11, 2020) (hereinafter "Affidavit").

15 See Affidavit, supra note 14, at 931 .

16 See id. (noting that Singer used one of his entities to disguise the payments' nature and source).
} 
respective universities' admissions offices as a commodity to sell. ${ }^{17}$ That clout, in the form of an admission slot for an applicant designated as a recruited prospective student-athlete, significantly improved the applicant's chance of admission. ${ }^{18}$ By designating applicants as prospective student-athletes when in fact the applicants were non-athletes, coaches exploited a gaping hole in the admissions process. ${ }^{19}$ Thus, ironically, one of the most recent major scandals in college athletics does not concern elite athletes but rather individuals who may not have even played high school sports. ${ }^{20}$ However, coaches happily accepted payment and/or donations to their programs in exchange for designating non-athlete applicants as recruited prospective student-athletes, as donations helped their programs. ${ }^{21}$

This article focuses on the intricate and crucial involvement of college athletics in Operation Varsity Blues, as it was an NCAA rule allowing for a special admission process for incoming student-athletes that created the side door for scheme participants. The article examines the resulting criminal proceedings, civil suits, and recently passed California legislation seeking to address the scandal, and questions whether they will effectively deter future similar schemes. The article suggests that the NCAA, as opposed to individual universities, lawmakers, and courts, is in the best position to prevent a future admissions scandal similar to Operation Varsity Blues. The article's organization is as follows. Section I details the NCAA's Special Admission exception that created the side door for the scandal. It also provides examples of occasions where wealthy families of non-athlete applicants used college coaches and an athletics department administrator to exploit the rule to facilitate side door admission to elite universities. Section II analyzes the ramifications that individuals and universities have faced, and will continue to face, as a result of their involvement in the scheme. For coaches and the athletics administrator, these ramifications include defending criminal charges and civil lawsuits, loss of employment, and NCAA penalties. The involved universities also face civil lawsuits and NCAA penalties, as well as a shifting industry standard requiring new policies and procedures for

\footnotetext{
17 See Andy Thomason, In Bribery Scheme, Coaches Sold Their 'Admissions Slots' to Nonathletes. Wait, Coaches Influence Admissions?, The Chronicle of Higher Education (Mar. 13, 2019), http://chronicle.com/article/In-Bribery-Scheme-Coaches/245891?cid=cp240 (detailing coaches' involvement in Operation Varsity Blues); see also Affidavit, supra note 14 (referring to admissions slots as universities' assets).

18 See id.

19 See id.

20 See Michael McCann, Potential Fallout From the Latest FBI-Investigated College Sports Scandal, Sports Illustrated (Mar. 12, 2019), https://www.si.com/college/2019/03/13/admissions-scandal-fbi-investigation-ncaa-violations-felicity-huffman-lori-loughlin-rick-singer (describing ties between Operation Varsity Blues and college athletics).

${ }_{21}$ See Thomason, supra note 17 (quoting Singer).
} 
university admissions. Many California universities also must comply with new state legislation aimed at combating admissions fraud. Section III scrutinizes the worthiness of the practice, permitted under NCAA legislation, whereby universities make exceptions to their stated admissions requirements for prospective student-athlete applicants. This article concludes by advocating for elimination of, or changes to, the NCAA's Special Admission exception.

\section{The NCAA Rule That Created the Side Door in Operation Varsity Blues and Individuals Who Exploited the Rule}

Many consider Singer's brainchild, Operation Varsity Blues ("Varsity Blues"), as the most severe higher education admissions scandal ever. ${ }^{22}$ The U.S. Attorney in the District of Massachusetts charged 50 people involved in the scheme with federal crimes, resulting in numerous plea deals and criminal proceedings. ${ }^{23}$

The scheme lasted eight years, during which time multiple iterations of university presidents, provosts, deans, and athletics directors failed to detect it. ${ }^{24}$ How is a scheme this broad and long-lasting even possible? How did this many individuals scheme and secure university admission for dozens of prospective students at academically prestigious universities through a side door without being caught? This section details the scheme's side door university admission route by examining both: (1) the NCAA rule that provided the side door and (2) how individuals exploited the rule to secure admission through the side door. ${ }^{25}$

\section{A. The Side Door: The NCAA's Special Admission Exception}

The NCAA is a voluntary organization that for years has served as universities' go-to organization for rules and regulations regarding athletics eligibility. ${ }^{26}$ It prides itself on its existence as "a member-led organization dedicated to the

\footnotetext{
22 See Jaschik, supra note 5.

23 See Zack Friedman, 30 Fast Facts About the College Admissions Scandal, Forbes (Mar. 18, 2019), http://forbes.com/sites/zackfriedman/2019/03/18/30-facts-college-admissions-scandal/\#20e06d8f12a0 (summarizing Varsity Blues).

24 See McCann, supra note 20 (noting that these individuals failed to detect wrongdoing and/or missed warning signs).

25 Note this article focuses more on the coaches and athletics administrator involved in facilitating side door admission, as opposed to the parents of the applicants admitted through the side door as the coaches and athletics administrator are more relevant to the article's analysis and suggestions.

26 See Jim Zimmerman, Will the NCAA Stand Its Ground?, The Sport Digest (Jul. 23, 2020), http://thesportdigest.com/2019/10/will-the-ncaa-stand-its-ground/ (identifying ramifications of California legislation regarding student-athletes' name, image, and likeness compensation).
} 
well-being and lifelong success of college athletes." ${ }^{27}$ Nearly 1,100 colleges and universities have chosen to join the NCAA and participate in athletics in one of three NCAA divisions. ${ }^{28}$ Almost half a million college athletes participate in NCAA athletics. ${ }^{29}$

Through a legislative process, individual NCAA Division I member universities may propose and vote on legislation. ${ }^{30}$ Through this process, member universities ultimately decide which rules the NCAA will adopt, which universities then have responsibility to implement and follow on campus. ${ }^{31}$

Several NCAA Division I rules state the academic requirements that an incoming student-athlete must satisfy prior to full-time enrollment at a member university in order to receive athletic-related financial aid and practice and compete in a sport on the university's behalf. ${ }^{32}$ In order to satisfy NCAA legislation regarding eligibility to practice, compete, and receive an athletics scholarship to participate in Division I athletics in a student-athlete's first year of full-time enrollment, an individual must: (1) complete 16 core courses in certain subjects on a specified timeline; (2) earn a core-course grade-point average of at least 2.300; (3) meet the NCAA's "sliding scale" for standardized tests and corecourse grade-point average; and (4) graduate high school. ${ }^{33}$ These are known as the NCAA's initial eligibility requirements.

Additionally, NCAA legislation mandates that an individual may not represent a university in Division I athletics unless the university admitted the student as a regularly enrolled, degree-seeking student under the university's published entrance requirements. ${ }^{34}$ Most relevant to this article, however, is the NCAA's "Special Admission" exception. This exception permits a university’s president, chancellor, or designated individual(s) to admit an incoming student-athlete who

\footnotetext{
27 What is the NCAA?, NCAA, http://ncaa.org/about/resources/media-center/ncaa-101/what-ncaa (listing basic information about the NCAA).

28 See id. (providing information on the NCAA's membership).

29 See id.

30 NCAA Division I Council-Governance Legislative Process, NCAA, http://ncaaorg.s3.amazonaws.com/governance/d1/legislation/2020-21/2020-21D1Gov_ConfLegislativeProcessInfo. Gr.pdf (describing council legislative process).

31 See What is the NCAA?, supra note 27 (answering query regarding who makes NCAA rules).

32 NCAA, 2019-20 Division I Manual § 14, et seq. (Aug. 2019), http://ncaapublications.com/productdownloads/D120.pdf (hereinafter "Manual"); see also Division I Academic Eligibility, Initial Eligibility, NCAA, http://ncaa.org/about/division-i-academic-eligibility (last visited May 14, 2020) (outlining Division I initial eligibility requirements).

33 Division I Academic Requirements, NCAA EligiBILITy CEnTER, http://fs.ncaa.org/Docs/eligibility_center/Student_Resources/DI_ReqsFactSheet.pdf (last visited May 14, 2020) (describing Division I initial eligibility requirements and associated timeline); see also NCAA, 2019-20 Division I MANUAL § 14.3.1.1 (Aug. 2019), http://ncaapublications.com/productdownloads/D120.pdf.

34 Manual, supra note 32, at $\S 14.1$.
} 
does not otherwise satisfy the university's admissions requirements if the university publishes an official document (e.g., official catalog) providing the individual(s) with such discretionary authority. ${ }^{35}$ Many universities take advantage of the exception and admit and enroll numerous incoming student-athletes annually who do not meet their published admissions requirements. Section III explores universities' widespread use of the exception, the exception's inconsistency with other NCAA legislation, and its lack of educational benefit. The following section details how scheme participants exploited the Special Admission exception to help applicants secure admission to academically elite universities.

\section{B. The Scheme and Relevant Participants}

Picasso said, "Learn the rules like a pro, so you can break them like an artist." On paper, the NCAA's Special Admission exception seems too innocuous to have greased the wheels of such a large admissions scandal. However, this section shows how Singer, college coaches, and an athletics administrator recognized that it was ripe for exploitation and used it to their advantage. When coaches and an athletics administrator designated applicants as potential student-athletes for their respective universities, it triggered a more lenient admissions process and criteria due to the Special Admission exception.

\section{Former Yale Soccer Coach Rudy Meredith}

Given college athletics's interesting and crucial role in Varsity Blues, it is fitting that the scandal came to light through a college coach. Federal authorities learned of the scheme when a suspect in another investigation provided a tip about a college coach who accepted bribes to secure athletic recruiting spots for prospective students..$^{37}$ In time, the FBI set up a sting in a Boston hotel room, where now-former Yale soccer coach Rudolph Meredith solicited a $\$ 450,000$ bribe from a parent in exchange for providing a roster spot for the parent's daughter. ${ }^{38}$ Unbeknownst to Meredith, the parent was a Justice Department tipster wearing a wire. ${ }^{39}$ Meredith was the first domino in the largest college

\footnotetext{
35 Id. at $\S 14.1 .2$.

36 See Goodreads, http://goodreads.com/quotes/558213-learn-the-rules-like-a-pro-so-you-canbreak.

37 See McCann, supra note 20 (noting the suspect hoped to receive leniency for cooperating).

38 See id; see also Dept' of Justice, Indictment 1 17-22, U.S. DEPT’ OF JusT. (Feb. 28, 2019), located at http://justice.gov/file/1142886/download (last visited June 19, 2020) (describing meeting between Meredith and applicant's father) (hereinafter "Meredith Indictment").

39 See Joey Garrison, A Yale Soccer Coach Caught in a Sting: How the FBI Broke Open the Sweeping College Admission Scandal, USA TodAY (Mar. 14, 2019), http://usatoday.com/story/ news/nation/2019/03/14/college-admissions-scandal-yale-womens-soccer-coach-meeting-rudy-meredith/3160494002/ (describing Meredith's involvement in federal investigation).
} 
admission scandal in U.S. history. ${ }^{40}$ Meredith became a cooperating witness in the federal investigation. ${ }^{41}$ Investigators pressed him, and Meredith led them to Singer, the bigger target. ${ }^{42}$

\section{College Admissions Consultant Rick Singer}

Singer, 58, was the racket's mastermind. ${ }^{43}$ Singer owns the for-profit college counseling company Edge College \& Career Network and serves as CEO of the non-profit Key Worldwide Foundation. ${ }^{44}$ For the past two decades, Singer portrayed himself as a college admissions expert who assisted 90,000 clients seeking college degrees. ${ }^{45}$ Over the past decade, Singer utilized a multi-step, yet straightforward scheme. ${ }^{46}$ Singer offered clients two tracks to securing university admission for their children. ${ }^{47}$ The first track involved assisting clients — parents of high school students - arrange for testing accommodations on standardized tests that permitted test-takers extra time to complete the tests. ${ }^{48}$ Singer would also bribe standardized exam administrators, such as 36-year old Mark Riddell, to complete exams in place of students or provide correct answers to students during exams. ${ }^{49}$

\footnotetext{
40 See id. Meredith achieved both individual and team success as Yale's women's soccer head coach before resigning in November 2018. Id. (describing both team's success and Meredith's individual accolades).

41 See Affidavit, supra note 14, at 922 . The allegations in the Affidavit do not identify Meredith by name, but several media entities identified Meredith using information from the federal documents. For example, see Garrison, supra note 39.

42 See The New York Times, College Admissions Scandal: Your Questions Answered, The New York Times (Mar. 14, 2019), http://nytimes.com/2019/03/14/us/college-admissions-scandal-questions.html.

43 See McCann, supra note 20 (profiling Singer).

44 See id. (describing Singer's ventures).

45 See Natalie Hope McDonald, All Your Questions About the College Admissions Scam, Answered, Vulture (Apr. 9, 2019), http://vulture.com/2019/04/college-cheating-scam-scandal-felicity-huffman-lori-loughlin.html (citing Singer's website).

46 See McCann, supra note 20 (describing scheme).

47 See Joey Garrison, Lori Loughlin Digs In - and 7 More Surprises and Takeaways in College Admissions Scandal, USA Today (Jun. 10, 2019), http://usatoday.com/story/ news/nation/2019/06/10/college-admissions-scandal-lori-loughlin-digs-and-7-more-takeaways/1350892001/ (describing scandal's key takeaways and big surprises).

48 See McCann, supra note 20 (describing use of falsified learning disabilities to gain extra time to complete exam).

49 See id. (describing Riddell's role).
} 
More relevant to this article is Singer's second track to university admission that used a network of college coaches and an athletics administrator. ${ }^{50}$ Using clients' funds, Singer bribed these contacts so that coaches recruited his clients' children as prospective student-athletes in order to obtain more leniency in the admissions process (via the Special Admission exception), even though the prospective students may not have even participated in high school sports. ${ }^{51}$

Singer went so far as to create fictitious athlete profiles of his clients' children that included made-up awards and staged photos that applicants submitted as university application materials. ${ }^{52}$ At times, Singer, his staff, and clients Photoshopped clients' children's faces onto athletes' bodies to make it look like applicants participated in athletics. ${ }^{53}$ Others staged photos of their children. For example, in order to help a daughter obtain admission to the University of Southern California ("USC"), Loughlin allegedly staged a photo of her daughter on an ergometer (a rowing machine) and claimed she was a skilled coxswain despite not rowing competitively or otherwise participating in crew. ${ }^{54}$ The stunt worked so well that Loughlin used it again months later with her younger daughter, an Instagram influencer. ${ }^{55} \mathrm{Her}$ admissions application falsely claimed that she was a coxswain for a club team and included an "action picture" of the daughter on

\footnotetext{
50 See id. (describing side of scheme involving college athletics). Singer charged clients more for participating in the recruitment scheme than in the test cheating scheme. See Garrison, supra note ${ }^{47}$ (noting that Loughlin faced more serious charges than Huffman due to Loughlin participating in the recruitment scheme).

51 See McCann, supra note 20.

52 See id. (providing example of staged photo of prospective student using a rowing machine or purportedly playing water polo); see also Affidavit, supra note 14, at $931 \mathrm{f}$ (noting Singer's statement that he fabricated profiles to "deceive" university admissions staff members).

53 See The New York Times, supra note 42 (answering common questions regarding Varsity Blues).

54 See Susanna Heller, Investigators Say Parents Were Editing Their Kids' Heads Onto Stock Photos of Athletes to Help Get Them Into Elite Colleges, Business Insider (Mar. 12, 2019), http:// businessinsider.com/investigators-parents-edited-kids-heads-onto-photos-of-athletes-to-get-theminto-college-2019-3 (describing lengths to which some wealthy parents went to secure admission of their children into academically-selective universities).

55 See id. (describing Loughlin's staged photos). One of Loughlin's daughters, social media personality Olivia Jade Giannulli, likely did not seek to attend USC for the intellectual experience. See Jaschik, supra note 5. In a widely panned video, Giannulli stated, "I don't know how much of school I'm gonna attend but I'm gonna go in and talk to my deans and everyone and hope that I can try and balance it all. But I do want the experience of, like, game days, partying ... I don't really care about school, as you guys all know." Id. Non-legal effects of Loughlin's ties to the scheme include Netflix dropping her from its Full House reboot. See Bogost, supra note 6 (listing results of Varsity Blues). The Hallmark Channel also cut ties with Loughlin. See Giulia Schaub, Civil Lawsuits Pile up Following Operation Varsity Blues, JurisMagazine (Apr. 2, 2019), http:// sites.law.duq.edu/juris/2019/04/02/civil-lawsuits-pile-up-following-operation-varsity-blues/ (describing civil suits stemming from Varsity Blues).
} 
an ergometer. ${ }^{56}$ However, coxswains do not row when racing, which could have tipped off an admissions staff member scrutinizing the materials. ${ }^{57}$

Singer accepted side door bribes totaling \$25 million over an eight-year period and helped facilitate prospective students' admission into academically selective universities including Yale University, Stanford University, Georgetown University, USC, and Wake Forest University. ${ }^{58}$ In a frightening turn of events for his clients, Singer pleaded guilty to various charges and became a cooperating witness for federal authorities, likely in an attempt to obtain leniency in sentencing. ${ }^{59}$

\section{Former Georgetown Head Tennis Coach Gordon Ernst}

Federal authorities allege Gordon Ernst, then the head tennis coach at Georgetown University, received more than \$2.7 million in bribes from Singer in exchange for designating at least 12 applicants as prospective tennis student-athletes to help facilitate their side door admission. ${ }^{60} \mathrm{~A}$ couple noteworthy examples indicative of Ernst's alleged involvement follow.

- A family conspired to bribe Ernst to designate its oldest daughter as a prospective tennis student-athlete to help facilitate her admission to Georgetown.$^{61}$ When Ernst received the applicant's transcript, he forwarded it to Georgetown's admissions office with the note, "Potential spot."

During the application process, Singer edited the daughter's Georgetown application essay to state:

\footnotetext{
56 See Heller, supra note 54.

57 See id. (noting that a high school guidance counselor questioned whether the girls actually rowed but USC ultimately admitted the daughters).

58 See McCann, supra note 20; see also Affidavit, supra note 14, at 131 (describing college recruitment scheme).

59 See McCann, supra note 20 (noting that Singer also likely provided documents to authorities).

${ }^{60}$ See Dep't of Justice, Indictment 9 84-85, U.S. DePT’ of Just. (Mar. 5, 2019), located at http://justice.gov/file/1142881/download (last visited July 11, 2020) (hereinafter "Indictment") (describing Ernst's involvement in the scheme). By the time news of the scandal broke, Ernst had left Georgetown and served as the women's tennis head coach at the University of Rhode Island ("URI"). See John Hilliard, Ex-Georgetown Tennis Coach, Facing Admissions Scandal Charge, Resigns as URI Women's Coach, Boston Globe (Mar. 23, 2019), http://bostonglove.com/metro/2019/03/23/ Georgetown-tennis-coach-facing-admissions-scandal-charge-resigns-from-uri-women-coac/s2uLGtPbV8066MHnvfldeO/story.html (describing Ernst's employment status). URI had placed Ernst on administrative leave around the time authorities charged him, and Ernst eventually resigned from URI. See id.

${ }^{61}$ See Affidavit, supra note 14, at 9 84-85 (describing involvement of Elizabeth and Manuel Henriquez, who is the founder, chairman, and CEO of a publicly traded specialty finance company).

62 See id. at 9117.
} 
[B]eing a part of Georgetown women's tennis team has always been a dream of mine. For years I have spent three-four hours a day grinding out on and off court workouts with the hopes of becoming successful enough to play college tennis especially at Georgetown. What is most amazing is how quickly I connected with Coach Ernst. He spent time with me while on campus and at several tournaments I played in. ${ }^{63}$

All of the information Singer included in the essay regarding tennis was false. ${ }^{64}$ The application contained additional false information regarding the applicant's tennis experience. ${ }^{65}$ For example, the application stated that the applicant earned a top 50 ranking in the United States Tennis Association ("USTA") Junior Girls Tennis while in high school; however, USTA records show that the applicant did not play in any USTA tournaments and at best was ranked 207 th in Northern California in the under-12 girls division where she won just two of her 10 matches. ${ }^{66}$

Georgetown ultimately admitted the applicant. ${ }^{67}$ One of Singer's entities paid Ernst $\$ 950,000$ in part for designating the applicant as a potential student-athlete to help secure her admission to Georgetown. ${ }^{68}$

- Another applicant whom Ernst designated as a potential student-athlete stated in her admissions materials she was a "ranked player" in high school when, in fact, the USTA has no record of her participation. ${ }^{69}$ Georgetown admitted the applicant, who did not participate in Georgetown's women's tennis program. ${ }^{70}$ For his role in securing the applicant's admission, Ernst received $\$ 244,000$ from Singer. ${ }^{71}$

- Ernst designated another applicant as a prospective men's tennis student-athlete, despite the fact that the applicant had never

\footnotetext{
${ }^{63} I d$. at 118 (noting the daughter's initial essay draft did not mention tennis).

64 See id.

65 See id. at 9120.

66 See id.

${ }^{67}$ See id. at 121 (noting that Georgetown performed an initial review of the daughter's application at Ernst's request).

68 See id. at 9123.

${ }^{69}$ See id. at 352 (describing scheme involvement of Elisabeth Kimmel, owner and president of media company and noting the USTA operates Southern California's Junior Tennis program).

70 See id. at 9355.

71 See id. at 935 (noting Singer's entities paid Ernst between $\$ 11,000$ and $\$ 24,000$ per month for a year).
} 
played tennis competitively. ${ }^{72}$ Singer's team fabricated an athletics profile for the applicant, and Ernst utilized one of his designated admissions slots to assist the applicant in securing admission. ${ }^{73}$ Georgetown admitted the applicant, and Singer paid Ernst for his assistance in securing admission. ${ }^{74}$ The applicant did not join Georgetown's men's tennis program. ${ }^{75}$

\section{Former University of San Diego Head Men's Basketball Coach}

\section{Lamont Smith}

Now-former University of San Diego ("USD") head men's basketball coach Lamont Smith's role in Varsity Blues was relatively limited. Smith sold two admissions slots to Singer in exchange for $\$ 110,000$ in bribes. ${ }^{76}$ For example, Smith helped a family obtain side door admission to USD for the family's applicant son. ${ }^{77}$ As part of the application process, Singer helped the family fabricate an athletics profile of the applicant, who did not participate in basketball. ${ }^{78}$ USD admitted the applicant, and Singer's team paid Smith for his assistance. ${ }^{79}$

\section{Former Stanford Head Sailing Coach John Vandemoer}

Singer made payments totaling nearly $\$ 800,000$ to an account associated with Stanford University's sailing program, then coached by John Vandemoer,

\footnotetext{
72 See id. at 482 (describing involvement of Stephen Semprevivo, an executive of a privately held provider of outsourced sales teams).

${ }_{73}$ See id. at 9 483-488 (describing applicant's application materials).

74 See id. at $940-491$ (describing payments).

75 See id. at 492.

76 See Indictment, supra note 60, at 123-127 (stating college athletics recruitment scam allegations relative to USD). Interestingly, the indictment refers to USD as "selective" while characterizing the other involved universities (Georgetown, Stanford, UCLA, USC, the University of Texas, Wake Forest, and Yale) as "highly selective." See id. at - 18-25.

77 See Affidavit, supra note 14, at 511 (stating allegations against Robert Flaxman, president and CEO of real estate development firm). The Affidavit does not identify Smith by name, but multiple news outlets identified him. For example, see Scott Phillips, Former San Diego Coach Lamont Smith Identified in College Admissions Scandal, YaHoo! Sports (Mar. 20, 2019), http://sports. yahoo.com/former-san-diego-coach-lamont-235002652.html (discussing Smith's involvement in scheme). After leaving USD after authorities dropped domestic violence charge against him, Smith became an assistant coach at the University of Texas, El Paso ("UTEP"). See Bret Bloomquist, UTEP Men's Basketball Assistant Coach Lamont Smith Resigns Amid College Admissions Scandal, Desert Sun (Mar. 19, 2019), http://desertsun.com/story/sports/college/utep/2019/03/20/ utep-mens-basketball-assistant-resigns-amid-bribery-scandal/3230056002/ (describing Smith's resignation from UTEP). Smith resigned from UTEP after USD informed UTEP of Smith's involvement in Varsity Blues. See id.

78 See Affidavit, supra note 14, at 9512 (describing applicant’s application materials).

79 See id. at 913,516 (describing involvement of Martin Fox in scheme).
} 
in exchange for Vandemoer designating applicants as prospective sailing student-athletes.$^{80}$ Similar to other coaches involved in the scheme, Vandemoer sold admissions slots to Singer's clients. ${ }^{81}$ For example, Vandemoer agreed to designate one of Singer's clients as a prospective sailing student-athlete in exchange for payment of $\$ 110,000$ from Singer. ${ }^{82}$ After the applicant elected to attend another university, Vandemoer agreed that another one of Singer's clients could use the admissions slot in exchange for payment of $\$ 500,000$ to Stanford's sailing program. ${ }^{83}$

\section{Former University of Southern California Athletics Administrator}

\section{Donna Heinel}

In fairness to the coaching profession, coaches are not the only college athletics employees who participated in the scheme. In fact, now-former USC athletics department administrator Donna Heinel was so crucial to Singer's scheme that the latter paid more than $\$ 1.3$ million to Heinel-controlled USC accounts for her assistance in securing admission to USC for Singer's clients. ${ }^{84}$ Thus, on average, Singer compensated Heinel between $\$ 50,000$ and $\$ 100,000$ for each of the dozens of applicants for whom Heinel helped secure side door admission. ${ }^{85}$ After she participated in the scam for a time, Singer rewarded Heinel by paying her $\$ 20,000$ per month. ${ }^{86}$

Heinel's extensive contributions to the Varsity Blues operation warrant brief mention of several of the more interesting and noteworthy examples of her involvement. Nearly every illustration follows a similar pattern. An applicant's

\footnotetext{
80 See Indictment, supra note 60, at 114-117 (describing Vandemoer's involvement in college athletics recruiting scam). After federal authorities identified Vandemoer as a key figure in Varsity Blues, Stanford fired him. See CBS SF, Stanford Sailing Coach Fired in Wake of College Admissions Scandal, KPIX CBS SF BayArea (Mar. 12, 2019), http://sanfrancisco.cblocal. com/2019/03/12/Stanford-sailing-coach-fired-in-wake-of-college-admissions-scandal/ (describing Vandemoer's involvement in scandal).

81 See Affidavit, supra note 14, at 308 (stating charges against John B. Wilson).

82 See Indictment, supra note 60, at 9 112, 114 (detailing Vandemoer's involvement in college athletics recruitment scam).

83 See id. at 115.

${ }^{84}$ See id. at 96,68 (describing Heinel's compensation for participation in the college athletics recruitment scam). USC fired Heinel after her indictment. See Greta Anderson, USC Fires Senior Athletics Officials, Inside Higher Ed (Jan. 15, 2020), http://insidehighered.com/quicktakes/2020/01/15/usc-fires-senior-athletics-officals (describing USC's termination of athletics administrators). Federal investigators are examining now-former USC athletics director Pat Haden's possible involvement in Varsity Blues. See Garrison, supra note 47 (noting Haden's tenure coincided with Khosroshahin and Janke's time at USC).

85 See id.

86 See id. at 97 (describing Singer’s compensation of Heinel).
} 
family was not confident that the applicant's academic credentials would, on their own, garner admission to USC. Thus, Singer would involve Heinel, who would advise Singer how to assist the applicant fabricate an athletics profile for the applicant indicating that the applicant would participate in a Heinel-selected sport at USC. Heinel or a USC coach would designate the applicant as a prospective student-athlete for the sport, and Heinel would falsely present the applicant as an incoming student-athlete to a USC committee that considered prospective student-athletes' admission applications. Singer would pay Heinel after USC admitted the applicant. The applicant would not participate in athletics at USC. More specifically:

- At Heinel's direction, Singer created a fake athletic profile of an applicant. ${ }^{87}$ The applicant had played lacrosse, but USC does not sponsor an NCAA lacrosse program. ${ }^{88}$ Singer and the applicant's father eventually settled on a fake profile advertising the applicant as a football kicker, even though the applicant's high school did not have a football team. ${ }^{89}$ Singer assured the applicant's father that the fake athletics profile would result in a $90 \%$ chance of USC admitting the applicant. ${ }^{90}$

- Perhaps most notoriously, Heinel helped facilitate the admission of Loughlin's two daughters to USC. Though Loughlin's oldest daughter did not participate in crew, Heinel presented Loughlin's daughter to USC's subcommittee for athletic admissions as a prospective crew student-athlete. ${ }^{91}$ USC admitted Loughlin's oldest daughter..$^{92}$ For her assistance, Heinel received $\$ 50,000$ from Loughlin's family. ${ }^{93}$

- Loughlin's family returned to the well for their younger daughter, using Singer and Heinel's assistance to secure admission of their younger daughter to USC. Again, Heinel presented a fabricated athletics profile of Loughlin's younger daughter as a crew coxswain

\footnotetext{
87 See Affidavit, supra note 14, at 143,147 (noting Singer claimed to have created "a million" fake athletic profiles for college applicants).

88 See id. (providing contents of a call between Singer and the applicant's father in which the father stated that he would not discuss the athletics profile in front of his son because the son knew he was not an athlete).

${ }^{89}$ See id at 146 (providing contents of a call between Singer and the applicant's father in which the two joke about the applicant having "really strong legs" and maybe turning into an actual football kicker).

90 See id. at 147.

91 See id. at 200 (noting the oldest daughter's academic qualifications were at the low end of USC's admissions standards).

92 See id. at 204 (describing Singer's \$200,000 fee for assisting with Loughlin's oldest daughter's admission to USC).

93 See id. at 201-202.
} 
for a club team. ${ }^{94}$ USC also admitted Loughlin's younger daughter. ${ }^{95}$ Again, Heinel received $\$ 50,000$ for her services. ${ }^{96}$

- Heinel also helped secure admission for an applicant whose application USC previously rejected. ${ }^{97}$ The candidate's subsequent application materials included fabricated information about her participation in crew. ${ }^{98}$ After USC's crew coach designated the previously rejected applicant as a crew recruit, USC admitted her. ${ }^{99}$ One of Singer's entities paid Heinel \$50,000 for her assistance. ${ }^{100}$

- Heinel helped secure side door admission to USC for another applicant using a fabricated water polo athletics profile. ${ }^{101}$ The applicant purchased water polo gear, including a ball and hat through Amazon. ${ }^{102}$ The applicant's family hired a graphic designer to create a fabricated photo of the applicant playing water polo. ${ }^{103}$ Heinel presented the applicant's application materials to USC's subcommittee for athletic admissions. ${ }^{104}$ After USC questioned the applicant's high school water polo participation, Heinel went so far as to lie to USC's admissions office that the applicant participated in nonscholastic, club water polo because the applicant's high school did not sponsor the sport. ${ }^{105}$ Heinel went on to describe the applicant's stature as "small but he has a long torso but short strong legs plus he is fast which helps him win the draw to start play after goals are scored." 106 USC admitted the applicant. ${ }^{107}$ The applicant's family paid Heinel $\$ 50,000$ for her assistance. ${ }^{108}$

- Heinel also assisted an applicant secure admission to USC as a purported football recruit. ${ }^{109}$ In this case, the applicant participated in high school football at one point and his mom described him

\footnotetext{
94 See id. at 9 208-210 (describing the athletic information in Loughlin's younger daughter's profile as false). 
as "not the team's star but a good solid player."110 Singer's team fabricated an athletics profile listing the applicant as a defensive lineman and long snapper. ${ }^{111}$ Heinel presented the applicant to USC's subcommittee for athletic admissions as a prospective football student-athlete at the position of long snapper. ${ }^{112}$ After USC admitted the applicant, his family paid Heinel $\$ 100,000 .{ }^{113}$

- Heinel assisted an applicant secure side door admission to USC by portraying him as an elite high school pole vaulter to USC's subcommittee for athletic admissions. ${ }^{114}$ The applicant's application materials included both a fabricated photograph of another individual participating in pole vault and statements describing the applicant's pole vaulting achievements. ${ }^{115}$ The applicant, however, never participated in pole vaulting, let alone the sport of track and field. ${ }^{116}$ USC admitted the applicant, and Heinel received \$250,000 for her assistance. ${ }^{117}$ The applicant never participated in track and field for USC. ${ }^{118}$

- In exchange for $\$ 50,000$ each and in a fashion similar to the aforementioned scenarios, Heinel assisted purported beach volleyball, women's volleyball, and women's lacrosse prospective student-athletes secure side door admission. ${ }^{119}$ Perhaps USC made it more difficult for Heinel to sell admissions slots for applicants designated as football student-athletes, as she received $\$ 75,000$ for assisting another applicant secure side door admission through USC's football program. ${ }^{120}$

- Heinel also presented an applicant attempting to secure admission to USC with a fabricated athletics profile as a prospective women's basketball student-athlete. ${ }^{121}$ In exchange for her assistance securing the applicant's admission, Singer began paying Heinel \$20,000 a

\footnotetext{
110 See id. at 942 (providing contents of phone conversation between Singer and Palatella).

111 See id. at 343 (noting the profile also portrayed the applicant as a member of local and state championship teams).

112 See id. at 344 (describing Heinel's portrayal of the applicant as false).

113 See id. at 346 (noting the applicant's family made the check out to the USC Women's Athletic Board).

114 See id. at $961-365$ (describing allegations against Elisabeth Kimmel).

115 See id. at 362,369 (describing fabricated statements like the applicant was one of the top pole vaulters in California).

116 See id. at $₫ 363$.

117 See id. at 371, 376.

118 See id. at 9377 (providing contents of phone conversation between Singer and Kimmel).

119 See id. at 9 379-399, 432-483, and 524-536 (describing allegations against Michelle Janvas, Diane Blake, Todd Blake, and Homayoun Zadeh).

120 See id. at 9 379-399 (describing allegations against Douglas Hodge).

121 See id. at 186 (noting the applicant had participated in high school basketball).
} 
month for her scheme contributions. ${ }^{122}$ The applicant eventually enrolled at USC but did not participate in women's basketball. ${ }^{123}$

- Heinel also assisted an applicant secure side door admission using one of the men's basketball program's admission slots. ${ }^{124}$ Singer's team was especially creative when fabricating this applicant's materials, stating that the applicant was 6-foot-1 tall when in fact he was 5-foot-5. ${ }^{125}$ As in other cases, Heinel presented the applicant to USC's subcommittee for athletic admissions and Singer paid her $\$ 50,000 .{ }^{126}$ USC admitted the applicant, who briefly attended USC but did not play basketball for the university. ${ }^{127}$

\section{Former University of Southern California Head Water Polo Coach}

\section{Jovan Vavic}

Jovan Vavic, USC's now-former water polo coach, assisted two applicants secure side door admission. ${ }^{128}$ In one instance, Heinel and Vavic teamed to facilitate an applicant's admission to USC as a prospective water polo student-athlete. ${ }^{129}$ Heinel used a fabricated athletics profile of the applicant describing her as a "3year Varsity Letter winner” and “Team MVP 2017," along with a photograph of another individual playing water polo, to advance her application at USC. ${ }^{130}$ Singer explained to the applicant's father that Vavic, in exchange for giving up one of his admissions slots, usually used payments from Singer to subsidize his staff members' salaries. ${ }^{131}$ The applicant's father paid \$50,000 for Vavic's assistance securing his daughter's admission to USC. ${ }^{132}$

\footnotetext{
122 See id. at 187 (stating that the original arrangement called for Singer to make a donation for an arena for USC's basketball and volleyball programs).

123 See id. at 191 (noting that Heinel and the applicant's father fabricated a story for USC's admissions department in which the applicant did not participate in women's basketball at USC due to an injury).

124 See id. at 473-480 (describing allegations against Macfarlane regarding his son).

125 See id. at 474 (describing the applicant's fabricated athletics profile).

126 See id. at 475, 477 (noting the applicant's family made their check out to USC Athletics).

127 See id. at $978-479$.

128 See Indictment, supra note 60, at 964 (describing Vavic's involvement in college athletics recruitment scam). Following his indictment, USC fired Vavic. See McDonald, supra note 45 (listing scandal's effects on individuals).

129 See Affidavit, supra note 14, at 222 (describing charges against vineyard owner Agustin Huneeus, Jr.).

130 See id. at 233, 234, and 238 (noting the applicant's father acknowledged to Singer that the applicant was not qualified athletically to participate on USC's water polo team).

131 See id. at 9231 (providing contents of a conversation between Huneeus and Singer).

132 See id. at 940.
} 
Vavic and Singer worked together to secure another applicant's admission through the side door using a fabricated water polo athletics profile. ${ }^{133}$ In fact, Vavic went so far as to lie to an athletics administrator that the applicant "would be the fastest player on our team, he swims $50 \mathrm{y}$ in 20 [seconds], my fastest players are around 22 [seconds], this kid can fly." 134 After USC admitted the applicant, the applicant's family paid $\$ 100,000$ to the USC's men's water polo program. ${ }^{135}$ The applicant withdrew from USC's water polo program after one semester at USC. ${ }^{136}$

\section{Former University of Southern California Soccer Coaches Laura Janke and Ali Khosroshahin}

Then-USC women's soccer coaches Laura Janke and Ali Khosroshahin helped facilitate side door admission for children of four of Singer's clients through the college athletics recruitment scam. ${ }^{137} \mathrm{~A}$ couple of examples follow.

- Using tactics similar to those previously described, Heinel, Janke, and Khosroshahin used a women's soccer admission slot for one of Singer's clients. ${ }^{138}$ For their services, the coaches received a combined \$150,000 through Singer's payment to a private women's soccer club team account. ${ }^{139}$ The applicant was admitted to, but did not participate in soccer for, USC..$^{140}$

\footnotetext{
133 See id. at 9 287-310 (describing allegations against John B. Wilson).

134 See id. at 297 (noting that this inaccurate information stemmed from the athletic profile Singer created).

135 See id. at 9 301. In exchange for Vavic's participation in the college athletics recruitment scam and under the guise of a fabricated scholarship, Singer made tuition payments for Vavic's children's private school. See Indictment, supra note 60, at 95 (noting Singer drew the payment on one of his charitable accounts).

136 See Affidavit, supra note 14, at 303.

137 See Indictment, supra note 60, at 62 (describing Janke and Khosroshahin's involvement in college athletics recruitment scam).

138 See Affidavit, supra note 14, at 9 400-406 (describing allegations against Douglas Hodge regarding his second daughter). Khosroshahin led USC's women's soccer program to a national championship in 2007, but USC fired him in 2013 after three consecutive mediocre seasons. See Joey Garrison, Ex-USC Soccer Coach Reverses Course, Agrees to Plead Guilty in College Admissions Scandal, USA TodaY (Jun. 3, 2019), http://usatoday.com/story/news/nation/2019/06/03/ ali-khosroshahin-former-usc-coach-makes-plea-deal-college-scandal/1332118001/ (summarizing Khosroshahin's involvement in Varsity Blues). Janke departed USC in 2014 after serving as an assistant coach there for seven seasons. See CBS Los Angeles, Former USC Soccer Coach Laura Janke Pleads Guilty in Admissions Bribery Scandal, CBS Los AngeLEs, http://losangeles.cbslocal.

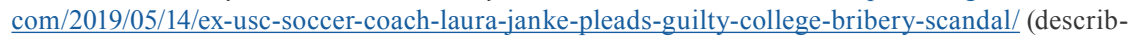
ing Janke's plea arrangement).

139 See Affidavit, supra note 14, at 9 407-415 (describing payments).

${ }_{140}$ See id. at 9416.
} 
- Heinel, Khosroshahin, and Janke teamed up to help another applicant secure side door admission through USC's women's soccer program. ${ }^{141}$ Consistent with other instances, Heinel presented a fabricated athletics profile of the applicant to USC's subcommittee for athletic admissions. ${ }^{142}$ Singer's team was especially creative in this applicant's admissions materials, as her application included the following fictitious essay statement:

On the soccer or lacrosse field I am the one who looks like a boy amongst girls with my hair tied up, arms sleeveless, and blood and bruises from head to toe. My parents have a hard time attending my soccer matches because our opponent's parents are always making rude remarks about that number 8 player who plays without a care for her body or anyone else's on the field. It is true that I can be a bit intense out there on the field. ${ }^{143}$

For their assistance, Khosroshahin and Janke received \$150,000 through their private soccer club and Heinel received \$50,000. ${ }^{144}$ USC admitted the applicant, who did not play soccer for USC. ${ }^{145}$

Janke's role in the scheme expanded to creating the fake athletic profiles for many USC side door applicants. ${ }^{146}$ One of the several profiles Janke created was for one of Loughlin's daughters. ${ }^{147}$ Janke received hundreds of thousands of dollars for creating fake athletic profiles. ${ }^{148}$

\section{Former University of California, Los Angeles Head Soccer Coach}

\section{Jorge Salcedo}

For payment of \$200,000, now-former University of California, Los Angeles ("UCLA") head soccer coach Jorge Salcedo helped secure side door admission to

\footnotetext{
141 See id. at 461-472 (describing allegations against Toby Macfarlane regarding his daughter).

142 See id. at 466.

143 See id. at 463-465 (describing falsified application materials).

144 See id. at 962,468 , and 472 (describing payments).

145 See id. at 971.

146 See CBS Los Angeles, supra note 138 (stating that Janke created "several" fake athletic profiles).

147 See id.

148 Seeid.
} 
UCLA for two of Singer's clients through the soccer program..$^{149}$ In one such case, Khosroshahin forwarded an applicant's information to Salcedo. ${ }^{150}$ After UCLA provisionally admitted the applicant, one of Singer's entities paid Salcedo's sports marketing company $\$ 100,000$ and Khosroshahin $\$ 25,000 .{ }^{151}$ Interestingly, Singer and Heinel worked together to secure admission to USC for the applicant's younger sister as a purported prospective rowing student-athlete, even though she was not competitive in rowing. ${ }^{152}$ Similar to other instances, Heinel presented a falsified athletics profile to USC's subcommittee for athletic admissions. ${ }^{153}$ After USC admitted the applicant, Singer paid Heinel $\$ 50,000 .{ }^{154}$

Amusingly, Salcedo filed a motion in U.S. District Court in Boston accusing UCLA of long using admission of student-athletes as a fundraising vehicle yet then feigning shock and outrage about the allegations involving him. ${ }^{155}$ More specifically, Salcedo contended that UCLA commonly utilized the student-athlete admissions process to admit individuals who failed to meet UCLA's rigorous academic or athletics standards in exchange for large donations from the applicants' families. ${ }^{156}$

\section{Former Wake Forest University Head Volleyball Coach William Ferguson} Then-Wake Forest University head volleyball coach William Ferguson designated one of Singer's client's children as a prospective volleyball student-athlete in order

\footnotetext{
149 See Indictment, supra note 60, at 9 93-108 (describing Salcedo's involvement in college athletics recruiting scam). Salcedo, who graduated from UCLA, coached his alma mater's men's soccer program for 15 seasons, during which he led the Bruins to four Pac-12 Conference titles. See Bill Hutchinson \& Sabrina Ghebremedhin, Former UCLA Soccer Coach to Plead Guilty in 'Varsity Blues' College Admissions Scandal, ABC News (Apr. 21, 2020), http://abcnews.go.com/ US/ucla-soccer-coach-plead-guilty-varsity-blues-college/story?id=70264819 (describing Salcedo's involvement in Varsity Blues).

150 See Affidavit, supra note 14, at 246 (noting that applicant's first choice of university was USC but USC began processing the applicant's materials through the regular admissions process due to a "clerical error," so the applicant applied to UCLA).

151 See id. at $9247-248$.

152 See id. at 9258 (noting the younger daughter "was an avid equestrian”).

153 See id. at $9258-260$.

154 See id. at 9263 (noting Singer began paying Heinel \$20,000 per month in July 2018).

155 See Nathan Fenno, Ex-Coach Charged in Admissions Scandal Accuses UCLA of Admitting Unqualified Athletes, Los Angeles Times (Jan. 24, 2020), http://latimes.com/sports/ucla/story/2020-01-24/soccer-coach-jorge-salcedo-accuses-ucla-admitting-unqualified-athletes (describing Salcedo's accusations against UCLA).

156 See id. (explaining Salcedo's argument that UCLA was not a victim of his role in Varsity Blues).
} 
to help secure her admission to Wake Forest. ${ }^{157}$ In exchange, Singer sent checks to accounts associated with Ferguson's volleyball endeavors that totaled $\$ 100,000{ }^{158}$

\section{Former University of Texas Head Tennis Coach Michael Center}

Singer paid then-University of Texas-Austin ("Texas") head tennis coach Michael Center $\$ 100,000$ in exchange for Center designating one of Singer's client's children as a prospective tennis student-athlete in order to help secure the applicant's admission to the university ${ }^{159}$ After Center designated the applicant as a potential tennis student-athlete and awarded him a scholarship that would pay for his textbooks, the university admitted him. ${ }^{160}$ Around the time the applicant began classes at Texas, he voluntarily withdrew from the tennis team and renounced his scholarship. ${ }^{161}$

As these incidents show, the scheme was intricate and involved numerous individuals who worked with Singer to exploit the NCAA's Special Admission exception. The following section details the ramifications these individuals face as a result of their involvement.

\footnotetext{
157 See Indictment, supra note 60, at 111 (describing Ferguson's involvement in college athletics recruiting scam). Ferguson resigned from Wake Forest months after authorities charged him. See Kate Murphy, Wake Forest Volleyball Coach Charged in National College Admissions Scandal Resigns, The News \& ObSERver (Aug. 23, 2019), http://newsobserver.com/news/local/education/ article234302432.html (describing Ferguson's Wake Forest tenure and resignation).

158 See Indictment, supra note 60 , at $\uparrow 110$ (describing bribe payments).

159 See id. at 9 119-121 (describing Center's involvement in college athletics recruitment scam). The Indictment does not name Center but several media entities have identified him as the relevant coach. For example, see Nate Raymond, Ex-University of Texas Tennis Coach Gets Six Months Prison for Admissions Scam, U.S. News (Feb. 24, 2020), http://usnews.com/news/us/articles/2020-02-24/ex-university-of-texas-tennis-coach-gets-six-months-prison-for-admissions-scam (describing Center's sentencing). Further, a separate Criminal Complaint names Center as the involved individual. See Dep’t of Justice, Criminal Complaint, U.S. Dep'T of Just. (Mar. 6, 2019), located at http://justice.gov/file/1142871/download (bringing Conspiracy to Commit Mail Fraud and Honest Services Mail Fraud charge against Center) (hereinafter "Criminal Complaint"). Texas fired Center after initially placing him on administrative leave. See Shannon Najmabadi and Jay Root, UT-Austin Fires Tennis Coach and Launches Internal Inquiry in Wake of National Bribery Scandal, TeXas Tribune (Mar. 13, 2019), http://texastribune.org/2019/03/13/texas-fires-tennis-coach-launches-internal-inquiry-after-bribery-scand//(describing university's actions related to Center).

160 See Criminal Complaint, supra note 159, at - 16-18 (describing Center's involvement in college athletics recruitment scam).

161 See id. at 25 (noting that the applicant would no longer be a student-athlete).
} 


\section{Ramifications for the Involved Coaches, Athletics Administrator, and Universities}

The ramifications for the coaches and athletics administrator involved in Varsity Blues are both serious and numerous, and include loss of employment and defending both criminal charges and civil lawsuits. ${ }^{162}$ Furthermore, a coach who assists incoming students skirt university admissions standards also implicates NCAA legislation. Coaches caught violating this legislation put their ability to work in college athletics at risk and can bring unwanted negative attention and penalties to the universities that employ(ed) them. A recent incident involving the University of Pennsylvania, described more fully below, provides an example of the application of NCAA legislation to, and NCAA penalties applicable to, a coach's involvement in a scheme to assist an incoming student evade university admission requirements.

In addition to likely NCAA sanctions, the universities involved in the scheme face civil lawsuits. Further, numerous universities have had to devote additional resources to their admissions processes as they implement new policies and procedures to try to mitigate the likelihood of a future admissions scandal. Universities also face the possibility of having to navigate and comply with new state legislation aimed at eliminating admissions fraud. This section examines these consequences that the involved coaches, athletics administrator, and universities have faced, and will continue to face.

\section{A. Relevant Criminal Charges, Outcomes, and Statutes}

At an indictment briefing, a U.S. attorney for Massachusetts promised, "There will not be a separate admissions system for the wealthy. And there will not be a separate criminal justice system either." ${ }^{\text {"63 }}$ This section, which reads like a final exam fact pattern in a white collar criminal law course, details some of the common criminal charges against the Varsity Blues defendants relevant to this article, provides the outcomes of pertinent criminal proceedings to date, and explains the statutes most applicable to remaining charges. Coaches' criminal sentences have been relatively light, casting doubt on whether criminal

\footnotetext{
162 See The New York Times, supra note 42 (describing myriad effects of the scandal on involved coaches).

163 See Jaschik, supra note 5 (quoting Lelling from March 2019 indictment briefing). At least one scholar has pointed to the irony that, as far as the law is concerned, a wealthy family may secure a child's admission to any university that is willing to exchange that spot for a sufficiently large donation; but the moment the family submits falsified application information, the government will treat it as a serious criminal offense punishable by imprisonment. See Nadler, supra note 11, at 1220 (providing example of Jared Kushner's admission to Harvard despite being a "mediocre high-school student" shortly after his father pledged a \$2.5 million gift to the university).
} 
prosecution of the Varsity Blues defendants will deter other coaches from participating in future similar schemes.

\section{Relevant Criminal Charges and Outcomes ${ }^{164}$}

In exchange for potential lenient sentencing, Singer pled guilty to racketeering conspiracy, money laundering conspiracy, conspiracy to defraud the United States, and obstruction of justice. ${ }^{165}$ The court has yet to sentence Singer, and the government recommended a sentence including incarceration at the low end of sentencing guidelines and three years of supervised release. ${ }^{166}$

Meredith, another cooperating witness, agreed to plead guilty to wire fraud, honest services wire fraud, and conspiracy to commit wire fraud. ${ }^{167}$ The court has yet to sentence him. ${ }^{168}$ Meredith hopes to obtain sentencing leniency in exchange for his cooperation. ${ }^{169}$

Authorities charged Vandemoer with racketeering conspiracy. ${ }^{170}$ Vandemoer pled guilty and likely cooperated with federal authorities in an attempt for leniency in sentencing. ${ }^{171} \mathrm{~A}$ federal judge sentenced Vandemoer to a day in prison. ${ }^{172}$ However, the judge concluded that Vandemoer had already served the sentence, so he will not spend time in prison. ${ }^{173}$ Vandemoer is also subject to two years of supervised release, and must serve the first six months in home detention. ${ }^{174}$

As part of a plea agreement, Center pled guilty to conspiracy to commit wire fraud and honest services wire fraud. ${ }^{175}$ The prosecutors recommended a sentence at the low end of the relevant penalty guidelines, and the court agreed. ${ }^{176}$

\footnotetext{
164 Authorities brought criminal charges against Heinel and all coaches listed above except for Smith.

165 See Indictment, supra note 60, at 90 (describing Singer's role as cooperating witness).

166 See Dep't of Justice, supra note 3.

167 See Indictment, supra note 60, at 92 (describing Meredith’s role as cooperating witness).

168 See Dep't of Justice, supra note 3.

169 See Indictment, supra note 60, at 922.

170 See Dep't of Justice, Complaint, U.S. Dep'T of Just. (Mar. 5, 2019), located at http://justice.gov/ file/1142906/download (bringing Racketeering Conspiracy charge against Vandemoer).

171 See McCann, supra note 20 (intimating that Vandemoer is cooperating with authorities). There is not a pattern explaining why some defendants were able to reach plea agreements while others were not. See Garrison, supra note 47 (analyzing defendants' legal strategies).

172 See Anderson, supra note 9; see also Dep't of Justice, supra note 3 (providing updates on charges against involved individuals).

173 See Anderson, supra note 9.

174 See Dep't of Justice, supra note 3 (describing resolution of charges against Vandemoer).

175 See Dep't of Justice, Plea Agreement, U.S. Dept' of Just. (Mar. 28, 2019), located at http://justice.gov/usao-ma/page/file/1152641/download (last visited June 21, 2020).

176 See Dep't of Just., supra note 3 (including table summarizing, among other things, charges and sentences).
} 
Center received a six-month prison sentence with a year of supervised release, along with forfeiture of $\$ 60,000 .{ }^{177}$ When he declined Center's request for a sentence without prison time, U.S. Court District Judge Richard Stearns admonished that Center's conduct weakened the public's confidence in the integrity of what should be a merit-based university admissions system. ${ }^{178}$

A grand jury indicted Ernst, Heinel, Janke, Khosroshahin, Ferguson, Salcedo, and Vavic on racketeering conspiracy charges. ${ }^{179}$ More specifically, U.S. attorneys for the District of Massachusetts alleged that each of these defendants engaged in at least two of the following criminal activities: mail fraud, honest services mail fraud, wire fraud, honest services wire fraud, and money laundering. ${ }^{180}$

Janke, Salcedo, and Khosroshahin entered plea agreements under which each pled guilty to the conspiracy to commit racketeering count. ${ }^{181}$ The court has yet to sentence any of them. ${ }^{182}$ Federal prosecutors recommended sentences including imprisonment at the low end of sentencing guidelines, along with a year of supervised release and restitution. ${ }^{183}$

Authorities brought additional charges against those defendants who have yet to cooperate and/or reach a plea arrangement—Ernst, Ferguson, Heinel, and Vavic - contending in a superseding indictment that:

- They owed a duty of honest services to their respective employers and failed to fulfill this duty when they designated applicants as recruited prospective student-athletes in order to secure side door admission in exchange for bribes. ${ }^{184}$

\footnotetext{
177 See id. (describing Center's sentence).

178 See Raymond, supra note 159 (describing Center's sentence).

179 See id. at 128-130 (alleging racketeering conspiracy charge).

180 See id. at 129 (describing allegations against defendants). To succeed in prosecuting under the racketeering statute, the government must prove that the defendants were engaged in a "pattern of racketeering activity," meaning they had to commit at least two separate crimes as part of a common scheme. See Page Pate, Racketeering Charges and Likely Defenses in "Operation Varsity Blues," PATE Johnson \& CHURCH (Mar. 12, 2019), http://pagepate.com/racketeering-charges-and-likely-defenses-in-operation-varsity-blues-indictment/ (characterizing mail fraud, honest services fraud, wire fraud, and money laundering as the government's "predicate offenses").

181 See Dep't of Just., supra note 3 (including table summarizing, among other things, charges and sentences).

182 See id.

183 See id.

184 See Dept' of Justice, Superseding Indictment $₫ 49$, U.S. DeP’T OF Just. (Oct. 22, 2019), located at http://justice.gov/usao-ma/page/file/1212316/download (last visited Jul. 15, 2020) (hereinafter "Superseding Indictment").
} 
- They committed mail and wire fraud and honest services mail and wire fraud. ${ }^{185}$

- Heinel and Ernst engaged in conspiracy to commit federal programs bribery. ${ }^{186}$

- Ernst committed federal programs bribery. ${ }^{187}$

- Ernst, Heinel, and Vavic engaged in wire fraud and honest services wire fraud. ${ }^{188}$

- Ernst and Heinel committed mail fraud and honest services mail fraud. ${ }^{189}$

- Ernst engaged in money laundering. ${ }^{190}$

These charges are serious and could result in the defendants spending decades in prison. ${ }^{191}$ And authorities possess damming evidence, including wiretapped phone conversations between Singer and many defendants. ${ }^{192}$

\section{Analysis of Relevant Criminal Statutes}

a. Racketeering. In March 2019, prosecutors charged many of the Varsity Blues defendants with violating the federal Racketeer Influenced and Corrupt Organizations Act ("RICO"). ${ }^{193}$ The government based its RICO charges on allegations that exam proctors, coaches, and administrators received payment in exchange for selecting undeserving student applicants for admission and/or athletics scholarships. ${ }^{194}$ According to federal authorities, one purpose of the

\footnotetext{
185 See id. at 147 (stating conspiracy to commit mail and wire fraud and honest services mail and wire fraud charge). Authorities charged Salcedo in the superseding indictment but he since reached a plea arrangement.

186 See id. at $148-155$ (stating conspiracy to commit federal programs bribery charges and federal programs bribery charge).

187 See id.

188 See id. at 156-157 (stating wire fraud and honest services wire fraud charges).

189 See id. at 158-159 (stating mail fraud and honest services mail fraud charges).

190 See id. at $158-159$ (alleging money laundering charge). In addition to Ernst, prosecutors charged many defendants not relevant to this article with money laundering charges. See Garrison, supra note 47 (contrasting defenses of Loughlin and Huffman).

191 See McCann, supra note 20.

192 See Garrison, supra note 47 (noting the government possesses three million pages of evidence, including one million pages of emails in addition to both 4,500 separate wiretapped phone conversations and Singer's bank records).

193 See Joey Garrison, Coaches in College Admissions Scam Call Charges an 'Unprecedented' Overreach of Mafia Law, USA TodAY (Oct. 17, 2019), http://usatoday.com/story/news/na$\underline{\text { tion/2019/10/17/coaches-athletics-officials-want-college-admissions-case-dismissed/3995739002/ }}$ (summarizing federal government's charges against defendants).

194 See Pate, supra note 180 (analyzing government's charges).
} 
conspiracy was facilitating applicants' admission to academically selective universities as recruited prospective student-athletes, regardless of their athletic abilities. ${ }^{195}$ The racketeering conspiracy occurred, in relevant part, when coaches and athletics administrators designated applicants as recruited prospective student-athletes, without regard for their athletics abilities, in exchange for bribes. ${ }^{196}$

With a stated purpose of eradicating organized crime by strengthening tools in the evidence-gathering process, establishing new penal prohibitions, and enhancing sanctions, RICO became law in $1970 .{ }^{197}$ Federal prosecutors appreciate RICO as a powerful tool designed to dismantle the heart of organized crimethe criminal conspiracy. ${ }^{198}$ RICO permits prosecutors to combine distinct acts by different defendants into a single, overarching RICO conspiracy. ${ }^{199}$ Additionally, RICO provides for lengthy prison sentences (up to 20 years or life for certain racketeering offenses). ${ }^{200}$

Historically, the Department of Justice ("DOJ") has used RICO to prosecute the mafia and other organized gang activity. ${ }^{201}$ For example, authorities used RICO to prosecute infamous mobster John Gotti. ${ }^{202}$ Similarly, prosecutors used RICO and "bare knuckle" white collar prosecution tactics to take down notorious mobsters like James "Whitey" Bulger and Anthony "Fat Tony" Salerno, and prosecute the heads of the infamous five families. ${ }^{203}$

Once federal authorities successfully utilized RICO to neutralize the mob in many major U.S. metropolitan areas in the 1990s, prosecutors began deploying RICO as a means of disrupting other large-scale conspiracies, such as public corruption and violent street gangs. ${ }^{204}$ After the infamous September 11, 2001, terrorist attacks, the DOJ repurposed RICO as a means to prosecute terrorism. ${ }^{205}$ The DOJ continued its creative uses of RICO more recently. For example, the DOJ used RICO to prosecute international soccer officials and executives associated

\footnotetext{
195 See Indictment, supra note 60, at 938 (listing racketeering conspiracy's purposes).

196 See id. at 939 (listing racketeering conspiracy’s means).

197 See John R. Mitchell, Steven A. Block, Sarah M. Hall, \& Mark R. Butscha, Jr., Beyond the Mob, 34 CRim. Just. 4, 5 (Fall 2019) (quoting RICO’s congressional purpose).

198 See id. (describing RICO as "powerful tool” for prosecutors).

199 See id. (identifying this purpose as a principal reason why prosecutors favor RICO charges).

200 See id.

201 See Garrison, supra note 193.

202 See Mitchell, et al, supra note 197, at 4 (analyzing DOJ's recent use of RICO).

203 See id. at 4, 6 (querying whether DOJ is overextending its reach).

204 See id. at 6-7 (describing RICO as "muscular" and citing as example RICO charge against former Illinois Governor Rod Blagojevich resulting from his alleged "auction" of the US Senate seat vacated when Barack Obama became President).

205 See id. at 8 (citing as example prosecutions of individuals with supposed ties to Hezbollah).
} 
with a FIFA soccer scandal and R\&B singer R. Kelly for an alleged pattern of racketeering activity including sexual exploitation of minors, kidnapping, and forced labor. ${ }^{206}$

The Varsity Blues defendants are a far cry from mob bosses, murdering hitmen, drug smugglers, and even street gangs and corrupt politicians. ${ }^{207}$ Thus, some consider federal authorities' use of RICO to prosecute the coaches and Heinel an overreach. ${ }^{208}$ The Varsity Blues defendants contend that each of their individual coordination was limited to coordinating with Singer, not with each other, making the case an "unprecedented attempt by the government to wildly expand the application of the RICO statute." ${ }^{209}$ If they can show they acted independently from each other and lacked criminal intent, the government will have difficulty proving the racketeering charges against the remaining defendant coaches and Heinel. ${ }^{210}$ In fact, multiple defendants filed motions seeking dismissal of the charges based on an argument that the defendants had no relationship or knowledge of each other's actions. ${ }^{211}$ For example, Heinel argued that each defendant's actions were "siloed," "parallel," and "uncoordinated," meriting dismissal of the government's charges. ${ }^{212}$

b. Honest services fraud and mail fraud. Honest services fraud charges were also common in Varsity Blues, thrusting the federal crime back into the spotlight. ${ }^{213}$ While the focus of the government's case is racketeering, it charged many of the defendants with honest services fraud, which, per its definition, does not involve the taking of money or property. ${ }^{214}$ In honest services fraud, a third party provides an enrichment to an employee who betrays his employer by

\footnotetext{
206 See id. (analyzing charges).

207 See id. (illustrating long, slow evolution of prosecutors' use of RICO); see also Pate, supra note 180 (cautioning against a rush to judgment, especially given that the defendants in Varsity Blues were guilty of things like cheating on standardized tests, not violence and extortion like in other racketeering cases).

208 See id.

209 See Garrison, supra note 193 (summarizing defendants' defense).

210 See Pate, supra note 180 (characterizing the government's chances of successfully prosecuting under RICO as "tricky").

211 See Garrison, supra note 193 (summarizing defendants' main defense).

212 See id. (describing Heinel's argument in a memorandum she filed).

213 See Gregory A. Bower \& Stanley L. Garnett, Honest Services Fraud Back in the Spotlight with “Operation Varsity Blues,” WLF Legal Pulse (Mar. 28, 2019), http://wlf.org/2019/03/28/wlflegal-pulse/honest-services-fraud-back-in-the-spotlight-with-operation-varsity-blues/ (portraying statute as controversial, especially when prosecutors use it for prosecuting private individuals).

${ }_{214}$ See Jonathan S. Jeffress \& William E. Zapf, Honest-Services Fraud in the Private Sector After Skilling v. United States: Continuing Vagueness and Resulting Opportunities for Clients, 43 Champion 26 (Sept./Oct. 2019) (examining prosecutions under honest-services fraud).
} 
acting secretively in self-interest. ${ }^{215}$ It is a type of fraud that deprives someone or something of an intangible service, such as an even playing field for students seeking college admission. ${ }^{216}$

Federal prosecutors often consider mail fraud as their bread and butter. ${ }^{217}$ Mail (or wire) fraud must include: (1) using the mail or other interstate carriers; (2) in conjunction with a scheme to intentionally defraud another of money, property, or honest services; (3) by means of material deception. ${ }^{218}$ When prosecuting RICO offenses, prosecutors often include the honest services statute because mail fraud is a natural offshoot of racketeering and can form a pattern of it. ${ }^{219}$

In the Varsity Blues prosecution, authorities allege that Heinel and the remaining coach defendants engaged in mail fraud and honest services mail fraud by scheming to defraud and obtain money and property-admission to universities - by false pretenses and to defraud and deprive universities of honest and faithful services of coaches and administrators through bribes. ${ }^{220}$ In doing so, these defendants used interstate carriers and wire communications. ${ }^{221}$

\section{B. Civil Suits Resulting from Operation Varsity Blues}

Federal prosecutors have not charged universities implicated in Varsity Blues with any crimes, even those who employed a coach and/or athletics department administrator who participated in Varsity Blues. ${ }^{222}$ Further, media coverage of

\footnotetext{
215 See id. [citing Skilling v. United States, 561 U.S. 358, 400 (2010)].

216 See Elden Law Group, Mail Fraud and Operation Varsity Blues, Elden Law Group (Nov. 25, 2019), http://eldenlawgroup.net/mail-fraud-and-operation-varsity-blues/ supra note 217 (analyzing charges).

217 See id. (analyzing mail fraud charges).

218 See id. (citing 18 U.S.C. $§ 1349$ ).

219 See id.

220 See Superseding Indictment, supra note 184, at 147 (stating conspiracy to commit mail and wire fraud and honest services mail and wire fraud charges against defendants including Ernst, Heinel, Ferguson, Salcedo, and Vavic).

221 See id.

222 See Friedman, supra note 23. Note the Education Department has written presidents of eight of the involved universities to request information to determine whether they broke rules associated with federal student aid programs. See Karen Weintraub \& Nick Anderson, Several Coaches Plead Not Guilty in College Admissions Bribery Scandal, The Washington Post (Mar. 25, 2019), http://washingtonpost.com/local/education/coaches-are-expected-in-federal-courtto-face-charges-in-college-admissions-bribery-scandal/2019/03/25/f18beab4-4f08-11e9-a3f778b7525a8df5 story.html (noting Education Secretary Betsy DeVos promised to look into the matter).
} 
Varsity Blues has focused on the involved celebrities, tycoons, and coaches. ${ }^{223}$ However, for every student one of these universities admitted through fraud and a side door, dozens or hundreds of perhaps more qualified applicants were unable to secure admission. This section analyzes the civil lawsuits that resulted from Varsity Blues and the unlikelihood that civil litigation will hold universities accountable for their involvement in the admissions scandal.

It is plausible that a parent of an applicant student whose application a university denied in favor of admitting someone who bribed her or his way into the university may be able to prove damage, especially if the denied applicant proves she or he met the university's admissions requirements. ${ }^{224}$ Applicants denied admission could seek treble damages, making civil cases extremely lucrative for any successful plaintiffs. ${ }^{225}$ Lengthy, expensive civil cases could impact these respected universities' bottom lines. ${ }^{226}$

Predictably, since the scandal, various civil lawsuits against the involved universities have surfaced, though none have been particularly successful to date. For example, plaintiffs filed a federal class action negligence lawsuit on behalf of "qualified, rejected" students against several universities in March 2019. ${ }^{227}$ Two Stanford University students filed the lawsuit in federal court in San Francisco. ${ }^{228}$ The complaint alleges the defendant universities denied the students a fair opportunity for admission due to the Varsity Blues scandal. ${ }^{229}$ More specifically, the plaintiffs brought suit on behalf of all individuals who paid an application fee and unsuccessfully applied to UCLA, USC, USD, Stanford, the University of Texas, Wake Forest, Georgetown, and/or Yale between 2012 and 2018. ${ }^{230}$ The lawsuit alleges that the universities accepted application fees but failed to ensure a fair admissions process free from fraud, bribery, cheating,

\footnotetext{
223 See Daniel Golden \& Doris Burke, The Unseen Student Victims of the "Varsity Blues" College-Admissions Scandal, THe New Yorker (Oct. 8, 2019), http://newyorker.com/books/page-turner/the-unseen-student-victims-of-the-varsity-blues-college-admissions-scandal (highlighting plight of applicants denied admission).

224 See id. (describing possible next steps in scandal fallout).

225 See id.

226 See id.

227 See Complaint - 5, 114, Erica Olsen and Kalea Woods vs. Singer, et al., Case 3:19-cv-01351 (N.D. CA 2019), located at http://scribd.com/document/401895247/College-Cheating-Class-Action-Lawsuit\#fullscreen\&from embed (hereinafter "Woods Complaint").

228 See id. An amendment to the complaint dropped one of the named plaintiffs, Olsen, less than 24 hours after they filed the lawsuit. See Steven M. Sellers, Stanford Student Dropped From College Bribery Case, Bloomberg LAW (Mar. 14, 2019) http://news.bloomberglaw.com/class-action/ Stanford-student-dropped-from-college-bribery-case-5 (detailing amendment to complaint).

229 See Woods Complaint, supra note 227, at 94.

${ }^{230}$ See id. at $₫ 6$.
} 
and dishonesty. ${ }^{231}$ Thus, the plaintiffs suffered an economic injury due to the unfair competition and the applicants seek return of their application fees. ${ }^{232}$ For example, one plaintiff alleges she had stellar standardized test scores and athletic talent, yet Yale rejected her after she paid $\$ 80$ to apply. ${ }^{233}$

The lawsuit goes on to allege that the Varsity Blues scheme resulted in admission of unqualified students at the expense of more deserving applicants. ${ }^{234}$ Additionally, the scandal decreased the value of students' degrees from the academically selective universities. ${ }^{235}$ The lawsuit seeks unspecified punitive damages "to punish the defendants and deter future conduct." 236 Legal maneuverings resulted in some plaintiffs dropping from the case and remaining plaintiffs re-filing it. ${ }^{237}$

From the outset, some legal experts felt the class action plaintiffs faced a challenge demonstrating that the scandal devalued a defendant university's' degree. ${ }^{238}$ However, the plaintiffs would have an easier time proving the loss of application money due to the alleged fraud. ${ }^{239}$ Perhaps more beneficial and interesting to the public would be the discovery process, which could shed light on the universities' admissions statistics regarding legacy, donations, and other relationships. $^{240}$

\footnotetext{
231 See id. at 77.

${ }_{232}$ See id. at 150.

233 See id. at $104-105$.

234 See id. at $94,5$.

235 See id. at $9107,110$.

236 See id. at 9138.

${ }^{237}$ The plaintiffs voluntarily dismissed their lawsuit without prejudice a day after filing it. Olsen, et al v. Singer, et al, Notice of Voluntary Dismissal Without Prejudice, 3:19-cv-01351, Pacer (N.D. CA) (Mar. 15, 2019). The docket entry for the notice of voluntary dismissal without prejudice is located at http://pacermonitor.com/public/case/27437164/Olsen_et_al_v_Singer_et_al. The Notice of Voluntary Dismissal is located at http://docketbird.com/court-documents/Olsen-et-al-vSinger-et-al/NOTICE-of-Voluntary-Dismissal-WITHOUT-PREJUDICE-by-Julia-Bendis-TylerBendis-Keri-Fidelak-Lauren-Fidalek-James-Johnson-Erica-Olsen-cand-5:2019-cv-01351-00006 (last visited July 7, 2020). Remaining plaintiffs re-filed their lawsuit. Bendis, et al v. Singer, et al, 5:19-cv-01405, Pacer (N.D. CA) (Mar. 15, 2019) (hereinafter "Bendis Docket").

238 See Doug Stanglin, 2 Stanford Students File First Class-Action Suit in Largest College Admissions Scam, USA TodaY (Mar. 14, 2019), http://usatoday.com/story/news/nation/2019/03/14/southern-california-yale-colleges-stanford-students-class-action/3160526002/ (quoting Jocelyn Larkin, former co-chair of the American Bar Association Section's Class Actions and Derivative Suits Committee and current executive director of the Impact Fund, which frequently joins economic and social justice class action lawsuits); see also Sellers, supra note 228 (citing interview of Steve Berman, managing partner of national class action law firm).

239 See id. (citing interview of Larkin).

${ }^{240}$ See id. (citing interviews of Larkin and Alexandra Lahav, class action expert and professor at the University of Connecticut School of Law).
} 
Another class action lawsuit surfaced when 26 unsuccessful applicants, or their parents, filed suit against Singer and the Varsity Blues universities that denied them admission. ${ }^{241}$ The complaint, filed in the U.S. District Court for the Northern District of California, is similar to the first class action suit. ${ }^{242}$ The plaintiffs allege that the eight defendant universities negligently failed to maintain "adequate protocols and security measures" to ensure the sanctity of the admissions process and to ensure their employees did not engage in bribery. ${ }^{243}$ The plaintiffs sought return of application fees, restitution, unspecified punitive damages, attorney fees, and an order enjoining the universities from continuing the "unfair business practices." 244 The plaintiffs allege that an application fee to each defendant university cost between $\$ 55$ and $\$ 100 .^{245}$

The Northern District of California consolidated the two class action cases and, on May 29, 2020, dismissed them without providing the plaintiffs leave to amend their allegations. ${ }^{246}$ Honorable Edward J. Davila concluded that the plaintiffs lacked standing and thus the court lacked jurisdiction to consider their claim. ${ }^{247}$ The defendants persuaded Judge Davila that the plaintiffs could not show that the scheme particularly affected them. ${ }^{248}$ More specifically, Judge Davila emphasized that Singer's scheme focused on athletics admissions slots. ${ }^{249}$ However, no plaintiff alleged that she or he applied for, was in consideration for,

\footnotetext{
241 See Joey Garrison, 14 More Rejected Students Sue Universities, Mastermind of Admissions Scheme, USA TodAY (Jun. 19, 2019), http://usatoday.com/story/news/nation/2019/06/18/14-more-rejected-students-file-class-action-suit-against-universities-mastermind-admissions-scheme/1489550001/ (describing class-action suit); see also Complaint, TAmBouRA, ET AL V. Singer, ET AL, Case 5:19-cv-03411-SVK (N.D. CA 2019), located at http://classaction. org/media/tamboura-et-al-v-singer-et-al.pdf (hereinafter "Tamboura Complaint").

242 See id.

243 See Tamboura Complaint, supra note 241, at 4.

244 See id. at 966,481 , and Prayer for Relief.

245 See id. at 429; see also Corrado Rizzi, Universities Facing More Possible Class Action Litigation Over Operation 'Varsity Blues' Findings, ClassAction.org (Jun. 19, 2019), http://classaction.org/news/universities-facing-more-possible-class-action-litigation-over-operation-varsity-blues-findings (describing lawsuit).

246 See Bendis Docket, supra note 237; TAMBoura, ET AL v. Singer, ET AL, 5:19-cv-03411, Pacer (N.D. CA) (Mar 15, 2019) (hereinafter "Tamboura Docket").

247 Order Dismissing Without Leave to Amend Bendis and Tamboura Plaintiffs' Amended Complaints for Lack of Standing, 2 Tamboura, et al v. Singer, et al, Case 5:19-cv-03411-SVK (N.D. CA 2019), Bendis, et al v. Singer, et al, Case 5:19-cv-01405-EJD (N.D. CA 2019), located at http:// courtlistener.com/recap/gov/uscourts/cand.339611/gov.uscourts.cand.339611.138.0.pdf.

Complaint, Tamboura, et al v. Singer, et al, Case 5:19-cv-03411-SVK (N.D. CA 2019), located at http://classaction.org/media/tamboura-et-al-v-singer-et-al.pdf

248 See id. at 6.

249 See id.
} 
or was denied an athletics admission slot. ${ }^{250}$ Thus, even if the scheme occurred as the plaintiffs alleged, the scheme did not particularly affect any of them. ${ }^{251}$ Thus, the plaintiffs failed to both plead an injury in fact and establish standing. ${ }^{252}$

Another class action lawsuit with named plaintiff Jennifer Kay Toy states allegations similar to the other cases - that the fraud and scandal deprived her son of a fair opportunity for admission at the universities. ${ }^{253}$ Toy's lawsuit brings negligent infliction of emotional distress, civil conspiracy, and fraud causes of action. ${ }^{254}$

However, a few things distinguish Toy's lawsuit. Unlike the other noteworthy lawsuits, she filed her lawsuit in state court - in the county of San Francisco. ${ }^{255}$ Further, instead of suing only the universities and Singer like the other lawsuits, Toy brought suit against them and dozens of individual defendants, including Loughlin, Huffman, Heinel, and the involved coaches. ${ }^{256}$ Finally, Toy's lawsuit seeks damages of at least $\$ 500,000,000,000{ }^{257}$

One class action expert believes an athletically talented applicant whose application a defendant university denied in favor of a fellow applicant lacking athletics skills and who received an admissions slot possesses a potentially viable claim. ${ }^{258}$ Given the number of lawsuits that already emanated from Varsity Blues, it would not surprise if such an individual surfaced and filed suit.

\section{NCAA Penalties}

In addition to employment ramifications and having to defend both criminal charges and civil lawsuits, the coaches and Heinel likely face NCAA penalties through its infractions process. The universities that employed them, already dealing with civil lawsuits, likewise face probable NCAA penalties. This section examines the NCAA infractions process and, through analyzing a recent infractions case involving the University of Pennsylvania, sheds light on the NCAA penalties that likely await the coaches and Heinel, and the universities that employed them during their involvement in Varsity Blues.

\footnotetext{
250 See id. at 6,8 .

251 See id.

252 See id. at 6.

253 Complaint 92 , 4, Jennifer Kay Toy, et al v. Lori Loughlin, et al, Case CGC-19-574501 (Superior Court of CA, County of San Francisco 2019), located at http://scribd.com/document/401920079/ Toy-vs-Loughlin-Et-Al-SF-Superior-Court (hereinafter “Toy Complaint”)

254 See id. at $162-82$.

255 See Toy Complaint, supra note 253.

256 See id.

257 See id. at Judgment Sought on pg. 11.

258 See Stanglin, supra note 238 (citing interview of Lahav).
} 


\section{NCAA Infractions Process}

The Enforcement Staff is an NCAA unit responsible for investigating possible violations of NCAA legislation. ${ }^{259}$ The Enforcement Staff possesses discretion whether to allege that an NCAA university, its employee(s), and/or studentathlete(s) violated NCAA legislation. ${ }^{260}$

The Division I Committee on Infractions ("COI") is an independent administrative body that considers cases in which the Enforcement Staff alleges that NCAA member universities, their employee(s), and/or student-athlete(s) violated NCAA rules. ${ }^{261}$ Current or former university presidents or chancellors, athletics directors, former coaches, faculty members, athletics compliance administrators, and general public members with formal legal training are among those who serve on the COI. ${ }^{262}$ The COI possesses jurisdiction to determine NCAA rules violations and prescribe appropriate sanctions. ${ }^{263}$

One method through which NCAA infractions cases resolve is via "Negotiated Resolution." In a case in which the Enforcement Staff, university, and involved individuals agree on the facts, violations, and penalties, the parties can pursue Negotiated Resolution as a means to resolve the matter. ${ }^{264}$ The parties can compile a report that the COI will review. ${ }^{265}$ The COI will approve the agreement unless it is not in the NCAA's best interests or if the parties' agreed-upon penalties are manifestly unreasonable. ${ }^{266}$

\section{University of Pennsylvania Infractions Case}

Recall from Section I.A. that the NCAA's Special Admission exception's latitude permits NCAA member universities to admit incoming student-athletes who fail to meet universities' general admission requirements. Because of this autonomy, a university is unlikely to violate NCAA rules only by admitting an incoming student-athlete who does not meet the university's published admissions requirements. However, as shown by a recent NCAA infractions case involving

\footnotetext{
259 Enforcement Staff, Enforcement: Division I Internal Operating Procedures § 1-1, http:// ncaaorg.s3.amazonaws.com/enforcement/D1Enf_EnforceIOP.pdf.

260 Id. at $\S 2-4$.

261 Committee on Infractions, Division I Committee on Infractions: Internal Operating Procedures $\S 2-1$ (Feb. 2020), http://ncaaorg.s3.amazonaws.com/committees/d1/infraction/D1COI_IOPs. pdf (hereinafter COI IOPs).

262 Id. at $\S 2-3$.

263 Id. at $\S 2-1-1$.

264 NCAA Enforcement, Division I Infractions Process, http://ncaa.org/enforcement/division-i-infractions-process (last visited May 15, 2020) (describing processes through which NCAA infractions cases transpire).

${ }_{265}$ Id.

266 COI IOPs, supra note 261, at § 4-9-1.
} 
the University of Pennsylvania described more fully below, college coaches can violate NCAA rules when attempting to help incoming students circumvent university admissions requirements.

The COI recently approved a Negotiated Resolution involving the University of Pennsylvania ("Penn"). The case illustrates how coaches can violate NCAA legislation by assisting incoming students circumvent university admissions requirements. It is also indicative of the NCAA penalties that await Heinel and the Varsity Blues coaches, and the universities that employed them.

Between May 2013 and March 2015, then-Penn head men's basketball coach Jerome Allen accepted $\$ 250,000$ from the father of a then-prospective student to train, recruit, and include his applicant son on a recruited prospective student-athlete list to increase the chances that Penn would admit the applicant. ${ }^{267}$ Penn learned of Allen's acceptance of bribes and other benefits from the applicant's family when it received an indictment in a federal criminal case alleging that the applicant's father engaged in Medicaid/Medicare fraud. ${ }^{268}$ While the applicant played high school basketball, Allen admitted in testimony in the father's trial that the applicant was not a good enough athlete to play at Penn. ${ }^{269}$ However, Allen placed the applicant's name on a recruited prospective student-athlete list in order to increase the likelihood Penn would admit him. ${ }^{270}$ Allen accepted money in exchange for the assistance he provided to the applicant's family. ${ }^{271}$

The violation did not occur due to Penn admitting the applicant. In fact, the COI concluded that neither Penn's athletics department nor admissions office deviated from university admissions processes when it admitted the applicant. ${ }^{272}$ In fact, the applicant's academic credentials were sufficient for admission to Penn with Allen's support. ${ }^{273}$ Instead, Allen violated NCAA ethical conduct principles

\footnotetext{
267 See Nat'l Collegiate Athletic Ass'n, University of Pennsylvania Public Infractions Decision, 1 (Feb. 26, 2020), http://web3ncaa.org/lsdbi/search/miCaseView/report?id=102828 (describing Negotiated Resolution regarding Penn's men's basketball) (hereinafter "Penn case"). The COI's public infractions decisions do not identify involved individuals by name but numerous media outlets identified Allen as the involved individual. For example, see Ben Pickman, Former Penn Coach Jerome Allen Hit With 15-Year Show-Cause Penalty, Sports Illustrated (Feb. 26, 2020), http://si.com/college/2020/02/26/jerome-allen-penn-basketball-show-cause-penalty (describing penalties resulting from Penn case).

268 Penn case, supra note 267, at 1 . Allen received shoes, concert tickets, and transportation in conjunction with the scheme. $I d$. at 3 .

269 Id. at 1.

270 Id.

271 Id. In 2018, Allen pled guilty to laundering some of the money he accepted. Id. at 2.

272 Id. at 7 .

${ }^{273}$ Id. The COI noted that the son ultimately graduated from the Wharton School at Pennsylvania in 2019. Id.
} 
and requirements by acting dishonestly and in an unsportsmanlike manner. ${ }^{274}$ More specifically, Allen accepted the payments and benefits without properly reporting and/or depositing them. ${ }^{275}$ Further, Allen's involvement in the scheme meant he failed to demonstrate a compliant atmosphere within his program as required by NCAA rules. ${ }^{276}$

Allen "recruited" the applicant for fall 2015 enrollment but resigned prior to the applicant's arrival on campus. ${ }^{277}$ Allen's replacement permitted the applicant to try out for the team and offered him a place on the junior varsity team, which the applicant declined. ${ }^{278}$ Ironically, the fact that the applicant never participated on the team mitigated the severity of the violations and accompanying penalties for Penn. While Allen deliberately concealed his conduct and used his position to influence the admissions process for personal financial gain, because the applicant never competed on Penn's behalf, the scheme did not provide a recruiting or competitive advantage to Penn or its men's basketball program. ${ }^{279}$

The COI concluded that Allen showed a reckless indifference to NCAA legislation and admonished that his actions seriously undermined or threatened the integrity of the NCAA Collegiate Model. ${ }^{280}$ Thus, the COI accepted the penalties applicable to Allen that the Enforcement Staff and Penn negotiated during the Negotiated Resolution process. ${ }^{281}$ The penalties included imposition of a 15-year show-cause penalty on Allen, meaning that if Allen sought an athletics-related position at an NCAA member institution within the 15-year period, the employing institution must show cause why Allen should have the ability to engage in any athletics-related activity. ${ }^{282}$ Further, in the year following the show-cause period, any employing university must suspend Allen for the first half of the season in which he coaches. ${ }^{283}$

\footnotetext{
274 Id. at 4 .

275 Id.

276 Id. NCAA bylaw 11.1.1.1 requires head coaches to promote a compliant atmosphere in their programs and monitor their staff members. Manual, supra note 32, at § 11.1.1.1. For a comparison between NCAA Bylaw 11.1.1.1 and vicarious liability under tort law, see Joshua Lens, NCAA Head Coach Responsibilities Legislation, 14 DePaul J. Sports L. 33 (2018).

277 See Penn case, supra note 267, at 2.

278 Id.

279 Id. at 5 .

280 Id.

281 Allen refused to participate in the investigation. Id. at 3.

282 Id. at 8 .

283 Id.
} 
Show-cause penalties can serve as scarlet letters that can effectively end coaches' careers in college athletics or at least blacklist them from finding work again for a certain period of time. ${ }^{284}$ The length of Allen's show-cause order, 15 years, matches the lengthiest show-cause order in COI history. ${ }^{285}$ By negotiating and approving the lengthy show-cause order, the Enforcement Staff and COI, respectively, showed how seriously they view situations where coaches use their positions within athletics to dishonestly circumvent admissions processes and/ or requirements.

Even though the applicant's enrollment did not lead to a recruiting or competitive advantage for Penn or its men's basketball program, because he was a Penn employee at the time of the violations, Allen's involvement in the scheme also led to consequences for Penn. The Enforcement Staff and Penn negotiated, and the COI approved, several penalties for Penn, including a fine, two years of probation, and recruiting restrictions for its men's basketball program. ${ }^{286}$ Perhaps just as harmful was that Penn had to go through the NCAA investigation and enforcement process, damaging its brand and reputation. Unfortunately, additional universities whose coaches engaged in the Varsity Blues scheme will likely suffer the same consequences as the NCAA infractions process ensues.

Allen went from serving as head coach of the program for which he played and earned university hall of fame honors to losing his job, conviction of a federal crime, and association with one of the Ivy League's biggest scandals. ${ }^{287}$ However, within months of Penn firing him, Allen landed on his feet, securing employment as an assistant coach with the NBA's Boston Celtics. ${ }^{288}$ The NCAA show-cause

\footnotetext{
284 See Joseph Duarte, Coaches Finding Life After "Kiss of Death," Houston Chronicle (Apr. 5, 2014), http://houstonchronicle.com/sports/cougars/article/Coaches-finding-life-after-kiss-ofdeath-5379846.php (profiling coaches who received show-cause orders). For additional analysis of show-cause orders and their legal status after a California state court invalidated them, see Josh Lens, Voiding the NCAA Show-Cause Penalty: Analysis and Ramifications of a California Court Decision, and Where College Athletics and Show-Cause Penalties Go From Here, 19 UNH L.R. 21 (2020).

${ }^{285}$ See Pickman, supra note 267 (noting that Allen now serves as an assistant coach for the Boston Celtics, where he is not subject to the NCAA's show-cause penalty).

286 Penn case, supra note 267, at 7-9. For an argument that the penalties unfairly punish Penn's current men's basketball staff and student-athletes, see The Daily Pennsylvanian Editorial Board, NCAA Sanctions Against Allen Unfairly Hurt Penn Men's Basketball, The Daily Pennsylvanian (March 1, 2020), http://thedp.com/article/2020/03/jerome-allen-ncaa-upenn-ivy-league-basketball (describing effects of penalties on Penn's current men's basketball staff and student-athletes).

287 See Theodoros Papazekos, A Year After the Scandal Broke, Penn Athletics Remains Quiet on Jerome Allen, The Daily Pennsylvanian (July 20, 2019), http://thedp.com/article/2019/07/pennathletics-jerome-allen-admissions-bribery-scandal-varsity-blues-ncaa-ivy-league-mens-basketball (describing aftermath of scheme involving Allen).

288 See Pickman, supra note 270 (quoting a Celtics spokesperson that Allen was forthright and contrite about his indiscretions at Penn).
} 
penalty only applies to athletics-related employment at NCAA member universities, and does not directly affect employment elsewhere, such as in professional sports. ${ }^{289}$

Like Allen, coaches at other academically selective universities allegedly accepted fat bribes in exchange for special admit slots for children of wealthy parents, some of whom never played sports in high school. ${ }^{290}$ These individuals include now-former coaches such as Vandemoer, Meredith, Ernst, Center, and Salcedo. ${ }^{291}$ As previously shown, Heinel, Ferguson, Janke, Khosroshahin, and Smith also engaged in activities that could subject them and their former employing universities to the NCAA infractions process and its ramifications. These individuals could face lengthy NCAA show-cause orders that could effectively end their college athletics careers. However, Allen serves as an example that it is still possible to obtain desirable employment in the sports industry despite ties to university admissions fraud.

\section{Universities' Implementation of New Policies and Procedures to Mitigate the Likelihood of Future Admissions Scandals}

"Operation Varsity Blues shook the world of college admissions." 292 In a sense, Singer and his scheme hacked college admissions. ${ }^{293}$ Following the scheme, universities asked themselves whether similar corruption occurred, or could occur, on their campuses. ${ }^{294}$ They also sought to identify steps they can, and should, take to protect the integrity of their admissions processes and standards. ${ }^{295}$ Universities across the country reacted strongly in the scandal's aftermath by

\footnotetext{
289 See id.

290 See Eric Olson, Special Admissions Called 'Original Sin' of College Sports, AP News (Mar. 16, 2019), http://apnews.com/a842ec11faa645b7adf5e75034e8bbf4 (describing role of special admissions process in Varsity Blues scandal).

291 See McCann, supra note 20 (stating that the universities who employed these coaches should expect NCAA punishments).

292 See Robbie Feinberg, How Maine Colleges Have Changed Their Admissions Procedures in the Wake of 'Varsity Blues' Scandal, Maine PuBlic (Dec. 19, 2019), http://mainepublic.org/post/howmaine-colleges-have-changed-their-admissions-procedures-wake-varsity-blues-scandal (describing Maine universities' actions in response to Varsity Blues).

293 See Rick Seltzer, Self-Reflecting After Varsity Blues, Inside Higher Ed (Sept. 30, 2019), http:// insidehighered.com/admissions/article/2019/09/30/admissions-field-still-coming-terms-varsityblues-scandal (quoting academic dean and director of college counseling at St. Christopher's School in Richmond, Virginia); see also Garrison, supra note 2 (stating that scandal "lifted the curtain" into college admissions underworld).

294 See Rosen, supra note 5.

295 See id.
} 
undertaking certain activities. ${ }^{296}$ First, many universities conducted audits to help determine whether coaches on their campuses had used athletics to assist incoming students circumvent general admission requirements. Additionally, many universities implemented certain monitoring activities or new policies in order to detect and deter any such future incidents. This section describes many of the more common auditing and monitoring activities and new policies. Universities that continue to employ a special admissions process for incoming student-athletes may consider undertaking them.

\section{Auditing Activities}

After news of Varsity Blues broke, many universities quickly audited records to determine whether similar issues occurred undetected on their campuses. Some universities, including the University of California, the elite public university system that includes the University of California, Berkeley, and UCLA, concluded that its insufficient recordkeeping prevented auditors from even determining its number of special admits in the first place. ${ }^{297}$ Further, the system lacked a set definition of the qualifications that could result in an applicant's eligibility for special admission. ${ }^{298}$

Brown University reviewed every enrolled varsity student-athlete to verify there was no attempt to compromise the integrity of the admissions process. ${ }^{299}$ Universities could examine whether recruited student-athletes ended up on a varsity athletics roster and, if not, the reason for the change. ${ }^{300}$ Such a review could discover situations common in Varsity Blues where a coach identifies an applicant as a prospective student-athlete in order to trigger the university's more lenient special admission scrutiny and, after admission, the student does not participate in the coach's sport.

296 See Lindsay Ellis, We Asked 20 Elite-College Admissions Deans About the Bribery Scandal. Here's What They Said. The Chronicle of Higher Education (Mar. 18, 2019), http://chronicle. com/article/We-Asked-20-Elite-College/245920 (detailing select universities' responses to Varsity Blues).

297 See Eric Quintanar, UC System Reveals Admissions Records for Student Athletes Incomplete, 'Basic Data' Unavailable, The DAILY WIRE (Feb. 19, 2020), http://dailywire.com/news/ uc-system-reveals-admissions-records-for-student-athletes-incomplete-basic-data-unavailable (describing audit results).

298 See id. (noting that for some students an audit identified as special admits, admissions officers were unable to explain why the students qualified for the exception).

299 See Ellis, supra note 296 (describing statement by the university's dean of admissions).

300 See id. (describing Brown University's audit). 


\section{Monitoring Initiatives and New Policies}

In the wake of Varsity Blues, higher education policymakers scrambled to bulletproof college admissions from scammers. ${ }^{301}$ Appropriate monitoring of improper use of athletics as an admissions side door begins with adequately documenting the criteria and processes under which incoming students qualify for special admit status. Universities may consider checks and balances on the process through which a coach or the athletics department designates prospective students as athletics recruits. ${ }^{302}$ Further, universities should track instances where incoming students benefit from the exception. ${ }^{303}$ These perhaps obvious actions would serve as the foundation for any monitoring activities (or help with future auditing activities, as evidenced by the University of California System audit previously described).

In order to reduce or eliminate undue influence on the admissions process, some universities sought to establish more of a firewall between the admissions and fundraising departments. ${ }^{304}$ Other universities implemented practices to monitor donations to prevent donors' influence on admissions decisions as well as other potential sources of conflicts of interest in admissions. ${ }^{305}$ Stanford adopted a policy stating that donors may not purchase admission of any applicant, nor should donors be of the impression they can purchase admission. ${ }^{306}$ The University of Virginia now prohibits solicitation or acceptance of donations from prospective student-athletes or their family members during the recruitment and

\footnotetext{
301 See Felicia Mello, Behind UC's 'Admission by Exception' Side Door: Sports, Money, Diversity-and Secrecy, CAL MatTers (Aug, 9, 2019), http://calmatters.org/education/higher-education/2019/08/college-scandal-admission-exception-uc-california-side-door-sports-money-diversity-secrecy/ (describing special admissions as a potential weak spot in college admissions).

302 See Thomason, supra note 1 (citing Johns Hopkins University as example).

303 See Alexis Duke, UC Makes Changes to Admissions Process in Recent Audit as Response to Scandal, Daily Bruin (July 21, 2019), http://dailybruin.com/2019/07/21/uc-makes-changes-toadmissions-process-in-recent-audit-as-response-to-scandal/ (describing University of California alterations in response to system audit).

304 See Feinberg, supra note 292 (quoting Jayne Fonash, the president of the National Association for College Admission Counseling).

305 See Duke, supra note 303 (describing University of California modifications in response to system audit); see also Katie Reilly, A Year After the College Admissions Scandal, Here's What Has (and Has Not) Changed, Time (Mar. 12, 2020), http://time.com/5801167/college-admissions-scandal-changes/ (stating that both UCLA and the University of California, Berkeley have started monitoring donations in an attempt to prevent them from affecting admissions decisions). 306 See Elena Kadvany, A 'Bulwark' Against Future Fraud: Stanford Announces Policy Changes in Response to Operation Varsity Blues, Palo Alto Weekly (Dec. 3, 2019), http://paloaltoonline. com/news/2019/12/03/a-bulwark-against-future-fraud-stanford-announces-policy-changes-in-response-to-operation-varsity-blues (describing new Stanford policy).
} 
application process. ${ }^{307}$ Similarly, UCLA will no longer accept donations from prospective student-athletes' families until after enrollment. ${ }^{308}$

Many universities promised to strengthen admissions processes. ${ }^{309}$ This could include addition of a disclaimer on application materials notifying applicants that their provision of inaccurate information could lead to loss of an offer of admission. ${ }^{310}$ Universities should implement stronger procedures for identifying any such inaccurate information, such as confirming incoming student-athletes' sport participation. ${ }^{311}$ At Yale, for example, both the admissions and athletics departments verify the athletics credentials of all potential student-athletes who receive a coach's endorsement. ${ }^{312}$ In fact, Yale's athletics director now reviews coaches' proposed recruits prior to sending them to the admissions office. ${ }^{313}$ USC will have three separate individuals review all incoming student-athletes' admissions files. ${ }^{314}$ Dartmouth University has its sport supervisors conduct the review. ${ }^{315}$ A member of Stanford's athletics executive leadership staff will review and confirm athletic credentials of all prospective student-athletes. ${ }^{316}$

Universities should also be suspect of situations where a recruited prospective student-athlete fails to make, or remain on, a team. Yale's athletics director reviews each instance where a recruited prospective student-athlete does not participate in a sport or leaves it early. ${ }^{317}$ Further, the athletics department conducts an exit interview with each such student-athlete regarding the departure from the team. ${ }^{318}$ Georgetown University conducts audits "periodically" to verify

\footnotetext{
307 See Scott Jaschick, Has Admissions Changed Since the Scandal?, Inside Higher Ed (Aug. 19, 2019), http://insidehighered.com/admissions/article/2019/08/19/has-admissions-changed-scandal (questioning whether Varsity Blues resulted in meaningful changes to college admissions).

308 See Fenno, supra note 155 (describing UCLA's remedial measures in response to investigation).

309 See Thomason, supra note 1 (citing Stanford University, Wake Forest University, and Yale University as examples).

310 See Duke, supra note 303 (describing Bowdoin College application process).

311 See Duke, supra note 303 (describing University of California audit recommendations).

312 See Yale University, Office of the President, Update - Actions to Strengthen Our Ability to Detect and Prevent Admissions Fraud (Aug. 28, 2019), http://president.yale.edu/speeches-writings/ statements/update-actions-strengthen-our-ability-detect-and-prevent-admissions (describing measures implemented after Varsity Blues) (hereinafter "Yale President Update").

313 See Thomason, supra note 1.

314 See id; see also Reilly, supra note 305 (stating that these three individuals work in the athletics department).

315 See id.

316 See Kadvany, supra note 306 (describing Stanford's actions following review of admissions process).

317 See Thomason, supra note 1

318 See Yale President Update, supra note 312 (describing exit interview as "thorough").
} 
whether students who coaches identified and recruited as athletes are actually on the roster for the sport program that recruited them. ${ }^{319}$ Dartmouth conducts an annual review to ensure that all recruited student-athletes appear on the appropriate team roster. ${ }^{320}$ USC conducts a similar audit of its athletics rosters twice a year. ${ }^{321}$ These efforts could help identify Varsity Blues-like situations where a coach designates an applicant as an athletics recruit in order to obtain leniency in admissions and then the individual does not participate in the coach's sport upon university admission and subsequent enrollment.

Universities and athletics departments may consider additional initiatives that focus on their coaches. Some universities implemented something akin to a "code of conduct" regarding recruiting. ${ }^{322}$ Universities could also strengthen their monitoring of coaches' receipt of athletics-related income. ${ }^{323}$ To do so, they could require coaches to complete and submit an annual disclosure form in which they disclose to the athletics department all instances where they receive income stemming from athletics.

As the aforementioned examples show, Varsity Blues could result in a shifting industry standard for universities everywhere regarding their special admission policies and procedures. These new processes will require additional resources devoted to admissions.

\section{E. State Legislation Aimed at Combating Admissions Fraud}

Following Varsity Blues, California lawmakers vowed to clamp down on the admissions process at their state universities. ${ }^{324}$ The State of California adopted the College Admissions Reform package, a set of legislation meant to address issues that the scandal brought to public attention. ${ }^{325}$ After California Governor Gavin Newsom signed the laws into effect, he stated,

\footnotetext{
319 See Thomason, supra note 17 (describing Georgetown's measures taken in response to Operation Varsity Blues).

320 See Thomason, supra note 1.

321 See Reilly, supra note 305.

322 See Ellis, supra note 296 (citing Yale as example).

${ }^{323}$ See Yale President Update, supra note 312 (noting requirement that coaches report all athletically-related income paid by an entity or individual other than Yale).

324 See Larry Gordon, Push for Tougher Laws Wanes Following California Admissions Scandal, EdSource (Sept. 13, 2019), http://edsource.org/2019/push-for-tougher-laws-wanes-following-california-admissions-scandal/617441 (describing California legislative initiatives responsive to Varsity Blues).

${ }^{325}$ See Alexandra Feldman, California Legislature to Increase Oversight of College Admissions, The Daily Californian (Jan. 15, 2020), http://dailycal.org/2020/01/08/california-legislature-to-increase-oversight-of-college-admissions/ (describing College Admissions Reform package).
} 
Higher education has the power to transform lives, and all hardworking young people in our state deserve a shot at it. This package of bills strikes at the forces that keep the doors of opportunity closed to too many people in our state. Together we're improving affordability, transparency and integrity in higher education. ${ }^{326}$

Other states could consider similar legislation that places new requirements on universities and attempts to increase transparency and accountability. This section analyzes California's attempt to address admissions fraud legislatively, concluding that while these new laws should help combat admissions fraud, they fall short of fully addressing the issues within university admissions that the federal government exposed in Varsity Blues. In fact, the California legislative process watered down the legislation, which possessed more teeth in its original version. ${ }^{327}$

\section{1. $A B 697$}

On October 4, 2019, Governor Newsom approved AB 697, which requires universities that belong to the California State University system to annually report to legislators whether they provided "any manner of preferential treatment in admission to applicants on the basis of their relationships to donors or alumni of the institution." ${ }^{328}$ For each such applicant, a university must provide certain information to the legislature, including the number of instances that the university offered admission to an applicant who did not meet the university's admission standards that apply to all applicants. ${ }^{329}$ AB 697 does not specify a use for the data. ${ }^{330}$

Assembly member Phil Ting, D-San Francisco, introduced AB 697. ${ }^{331}$ Ting stated:

We must strive for a level playing field in the college admissions process, so there can be equal opportunity for all. We should know how prevalent donor and alumni-based preferential treatment is in California, so we can compare that to the amount of state-funded benefits, like CalGrants, flowing toward the school. ${ }^{332}$

\footnotetext{
326 See Ashley A. Smith, Gov. Newsom Signs Bills to Expand College Student Aid, Target Admissions Scandal, EdSource (Oct. 4, 2019), http://edsource.org/2019/gov-newsom-signs-bills-to-expand-college-student-aid-target-admissions-scandal/618207 (describing California laws).

327 See id. (comparing legislation proposals).

328 Assem. Bill 697, 2019, 2019 Cal. Stat. http://leginfo.legislature.ca.gov/faces/billTextClient/ xhtml?bill id=201920200AB697.

329 Id.

330 See Gordon, supra note 324 (noting that the bill's purpose is to bring more fairness and transparency to college admissions).

331 See Feldman, supra note 325.

332 Id.
} 
Ting went on to describe AB 697:

This bill is about fairness and equity. We raise our kids to believe that if they work hard, all opportunities will be open to them. But that's just not true when it comes to college. We must close the side door that enables privileged families to get their children into elite colleges and take spots away from deserving students. ${ }^{333}$

An earlier version of the bill went much further and may have better accomplished Ting's objectives, as it would have prohibited universities that provide admissions preference to alumni or donors' children from receiving state financial aid. ${ }^{334}$ While the final version of the AB 697 that became law requires universities to track and report certain information regarding special admissions, there is no mention in the bill of any ramifications for universities when they offer admission to an alumni or donor's child - or an incoming student-athlete-who does not meet regular admission requirements. Further, there is no mention of any steps the legislature should, or will, take when it receives the information. Thus, the law does not place much accountability on the universities to which it applies.

\section{2. $A B 1383$}

Another bill attempting to address issues stemming from Varsity Blues that Newsom approved and California adopted into law is AB 1383. AB 1383 prohibits California State University system member universities from admitting an applicant by exception unless at least three senior campus administrators approve it prior to the applicant's enrollment. ${ }^{335}$ Exceptions exist for applicants who are California residents receiving an institution-based scholarship or who the university admits via an educational opportunity program. ${ }^{336}$ Member

\footnotetext{
${ }_{333}$ See Olivia Gonzalez Britt, CA Gov. Gavin Newsom Signs AB 697, Addresses College Admissions, The Daily Californian (Oct. 8, 2019), http://dailycal.org/2019/10/08/ca-gov-gavin-newsomsigns-ab-697-addresses-college-admissions/ (describing the legislation).

334 See Smith, supra note 326 (noting that AB 697's final version "didn't go nearly as far" as earlier versions of the bill); see also Assem. Bill 697 3/28/19 version, 2019 http://leginfo.legislature. ca.gov/faces/billVersions/CompareClient.xhtml?bill_id=201920200AB697\&cversion=20190AB69798AMD. Private universities successfully lobbied opposition against harsher versions of $\mathrm{AB} 697$, arguing that the proposal would have punished the low-income students who depend on state financial aid to help cover their tuition. See Larry Gordon, Private California Colleges Win Changes in Scandal-Related Legislation, EDSource (May 1, 2019), http://edsource.org/2019/private/california-colleges-win-changes-in-scandal-related-legislation/611763. Further, the original version of AB 697 would have interfered with these universities' traditions of maintaining family ties in a relatively small number of cases. See id.

335 Assem. Bill. 1383, 2019, 2019 Cal. Stat. http://leginfo.legislature.ca.gov/faces/billTextClient/ $\underline{\text { xhtml? bill id }=201920200 \mathrm{AB} 1383}$.

336 Id.
} 
universities who admit applicants by exception into an athletics program must establish a policy requiring such students to participate in the program for a minimum of one academic year. ${ }^{337}$

An earlier version of the bill contained language suggesting that certain individuals - the chancellor, president, vice president, vice chancellor, provost, director of admissions, and a faculty member- determine the applicant's fate. ${ }^{338}$ As the bill progressed through the legislative process, the language disappeared and became vaguer, requiring only that three senior level campus administrators approve the admission. This review independent from athletics is not foolproof, as evidenced by what occurred at USC as part of Varsity Blues. USC had a similar setup that Heinel was still able to abuse when she assisted applicants obtain side door admission. Like AB 1383's requirement, USC's process required Heinel to present special applicants to USC's subcommittee for athletic admissions. This subcommittee approved admission for dozens of applicants who portrayed themselves as incoming student-athletes yet many were not athletically proficient or would participate in athletics at USC. Thus, while AB 1383's requirement of an independent review outside of athletics adds another layer in the special admission process, it likely will not prevent or lessen admissions fraud such as that which occurred at USC. In fact, a University of California spokesperson confirmed that the legislation will most likely not majorly affect admissions at the University of California, Berkeley or other University of California campuses. ${ }^{339}$

$\mathrm{AB}$ 1383's requirement that a special admit into an athletics program must participate in the program for at least an academic year strengthens the bill but lacks specificity. The bill does not provide a penalty if the student is not part of the athletic program for an academic year. ${ }^{340}$ Further, the bill does not describe the level of participation that the student must maintain. Does the student have to remain an active student-athlete on the athletics roster, for example? Or can a coach make the applicant a student manager and fulfill AB 1383's academic year requirement of program participation? In the Varsity Blues scandal, Khosroshahin forwarded Salcedo an applicant that the former identified as a "soccer player/student manager." ${ }^{341}$ UCLA admitted the applicant. ${ }^{342}$ If a coach at one of the California System universities could help obtain side door admission for an

\footnotetext{
337 Id.

338 Assem. Bill 697 4/1/19 version, http://leginfo.legislature.ca.gov/faces/billVersionsCompareClient.xhtml?bill_id=201920200AB1383\&cversion=20190AB138397AMD.

339 See Feldman, supra note 325 (citing interview of Sarah McBride, a University of California Office of the President spokesperson).

340 See Gordon, supra note 324.

341 See Affidavit, supra note 14, at 9246.

342 See id. at 247.
} 
applicant and then make the applicant a student manager who washes towels and cleans up the locker room for an academic year without that individual clogging up a roster spot, receiving an athletics scholarship, and/or receiving playing time, AB 1383's academic year requirement does not dissuade a coach from assisting an applicant obtain side door admission.

\section{3. $A B 1312$}

Another bill, $\mathrm{AB}$ 1312, sought to regulate the kind of business - university admissions consulting -in which Singer engaged. ${ }^{343}$ AB 1312 would have both required registration and created an oversight mechanism for university admissions consultants. ${ }^{344}$ However, the bill stalled in the Senate Appropriations Committee. ${ }^{345}$

Similar to individual universities, states may attempt to regulate university admissions policies and procedures to address Varsity Blues. When combined with the additional policies and procedures universities must implement to reach a shifting industry standard, universities that were not involved in Varsity Blues still face the likelihood of devoting additional resources to the admissions process. For those universities involved in Varsity Blues, they face civil suits and, likely, NCAA penalties, too.

\section{Other Downsides to, and Effects of, the NCAA's Special Admission Exception}

Notably, the NCAA rule permitting a university to admit incoming studentathletes who do not meet its stated admission requirements is permissive legislation, meaning that universities do not have to engage in the practice. This section describes many of the negative outcomes associated with the Special Admission exception. Due to these numerous and often severe consequences, perhaps some universities, states, and/or the NCAA will consider eliminating, changing, or curbing use of the exception.

\section{A. Potential for Admissions Fraud and Indiscretion and Accompanying Ramifications}

First, as previously detailed, the NCAA's Special Admission exception helped tempt numerous individuals in higher education, including renowned coaches

\footnotetext{
${ }^{343}$ See Gordon, supra note 324 (stating AB 1312 attempted to put a clamp on crooked college admissions consultants); see also Assem. Bill. 1312, 2019, http://leginfo.legislature.ca.gov/faces/ billTextClient.xhtml?bill_id=201920200AB1312.

344 See id.

345 See Gordon, supra note 324 (noting the stall is due to concerns over potential costs).
} 
and an athletics administrator, to scheme to admit applicants to elite universities through a side door. The ensuing federal criminal investigation and civil lawsuits are a black eye for higher education and the involved universities. Additionally, Penn and its now-former head men's basketball coach received sanctions through the NCAA infractions process after an admissions scandal involving a single applicant. The universities and coaches involved in Varsity Blues likely face similar outcomes.

\section{B. Inconsistency with NCAA Legislation and Principles}

Further, the Special Admission exception is inconsistent with other, longstanding NCAA legislation. The fact that, due to the existence of the exception, incoming student-athletes can face a different admissions review with less rigorous requirements than incoming non-athlete students runs counter to other NCAA legislation and values.

\section{NCAA Extra Benefits Legislation}

For example, NCAA rules strictly prohibit student-athletes from receiving any "extra benefit." ${ }^{346}$ The NCAA defines an extra benefit as a benefit that is unavailable to non-athlete students and determined on a basis related to athletics ability. ${ }^{347}$ When an incoming student-athlete faces less stringent admissions requirements because she or he will participate in a university's sport program, the incoming student-athlete receives a benefit unavailable to non-athlete students on the basis of the incoming student-athlete's status as an athletics participant (or at least perceived athletics participant in the Varsity Blues context). This is counter to the rationale behind the NCAA's prohibition on extra benefits.

While NCAA legislation states that a university's use of the Special Admission exception is permissible only if the university offers the same opportunities to non-athletes, several studies show that student-athletes disproportionately benefit from the exception. ${ }^{348}$ For example:

- A 2009 Associated Press review identified over two dozen universities where incoming student-athletes were more than 10 times more likely to benefit from special admission preference than non-athlete students. ${ }^{349}$

\footnotetext{
346 Manual, supra note 32 , at $\S 16.01 .1$.

347 Id. at $\$ 16.02 .3$.

348 See Associated Press, Report: Exemptions Benefit Athletes, ESPN (Dec. 30, 2009), http://espn.

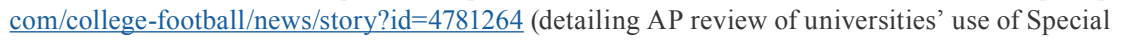
Admission exception).

349 See id. (describing special admissions exception usage as "widespread" and taking place in
} 
- Incoming football student-athletes at one of the nation's most selective public universities, the University of California, Berkeley, were 43 times more likely to benefit from a special admissions decision than non-athletes from 2002 to $2004 .{ }^{350}$

- Harvard's acceptance rate is 5\% of all applicants compared to an $86 \%$ acceptance rate for incoming students designated as athletics recruits. $^{351}$

- In 2011, UCLA admitted half of its student-athletes as special admits - including $85 \%$ of scholarship football student-athletescompared with less than $2 \%$ of the rest of its incoming freshman class. ${ }^{352}$

Trends in this data are not new; the consistency spans decades. For instance, a 1991 survey by The Chronicle of Higher Education showed that Division I football and men's basketball student-athletes were six times more likely than other students to obtain admission via the Special Admission exception. ${ }^{353}$ These statistics run directly counter to the principles behind NCAA extra benefits legislation requiring universities to treat student-athletes the same as non-athletes-legislation that the NCAA takes so seriously that the penalty for violating it is extremely severe. ${ }^{354}$ When a student-athlete receives an extra benefit, the student-athlete is ineligible to compete in any NCAA-sponsored sport for an NCAA member university. ${ }^{355}$

\section{NCAA Recruiting Legislation}

In addition to extra benefits legislation, universities' current use of the NCAA's Special Admission exception runs counter to NCAA recruiting regulations. NCAA rules prohibit university staff members and athletics representatives from directly or indirectly making arrangements for, or giving benefits to,

every major conference).

350 See id. (quoting then-admissions director as stating that the university treated incoming student-athletes the same as oboe players).

351 See Anderson, supra note 9.

352 See Mello, supra note 301 (detailing University of California system's special admit process).

353 See Douglas Lederman, Special Admissions Treatment for Athletes Widespread at Big-Time Sports Colleges, The Chronicle of Higher Education (May 1, 1991), http://chronicle.com/article/ Special-Admissions-Treatment/86561 (noting that 27\% of football and basketball student-athletes were special admits compared to $4 \%$ of all other students).

354 Thirty years ago, NCAA executive director Richard D. Schultz unsuccessfully proposed a certification program requiring universities to offer special admission to roughly the same proportion of incoming student-athletes to non-athlete students. See Lederman, supra note 353.

355 Manual, supra note 32, at $\S 16.01 .1$. 
a prospective student-athlete, other than those expressly permitted by NCAA rules. ${ }^{356}$ Like extra benefits legislation, NCAA recruiting rules state that receipt of a benefit by a prospective student-athlete does not violate NCAA rules if the same benefit is available to non-athlete prospective students. ${ }^{357}$ While NCAA rules permit universities to invoke the Special Admission exception for incoming student-athletes, a university must utilize it for admitting both incoming studentathletes and non-athlete students for its usage to be permissible. However, the aforementioned data shows that incoming student-athletes benefit from a special admissions process at a rate disproportionately higher than non-athlete incoming students. Thus, many universities utilize the Special Admission exception in a manner inconsistent with general NCAA recruiting inducement rules.

\section{Inconsistency Between Universities' Policies and the Resulting Pressures and Uneven Playing Field}

Universities' policies regarding the Special Admission exception for incoming student-athletes vary widely between universities, resulting in an uneven playing field. ${ }^{358}$ Some states have enacted laws requiring universities to admit individuals who satisfy NCAA initial eligibility criteria. ${ }^{359}$ Other states cap the number of annual special admits at state universities. ${ }^{360}$ For example, up to $6 \%$ of each University of California System member university's entering class can include applicants who do not meet the System's minimum admission standards but possess a special talent or are from a disadvantaged background. ${ }^{361}$ Many universities provide considerable discretion to their admissions committees and have low academic standards for admission via the exception. ${ }^{362}$ Federal officials who investigated the universities involved in Varsity Blues concluded that a coach's designation of an applicant as a potential student-athlete virtually

\footnotetext{
$356 \quad I d$. at $\S 13.2 .1$.

357 Id.

358 See Kevin Kiley, A New Playbook, Inside Higher Ed (Oct. 5, 2012), http://insidehighered.com/ news/2012/10/05/public-university-admissions-officers-lay-out-best-practices-athlete-admissions (providing suggested best practices for Special Admission exception processes and procedures for incoming student-athletes).

359 See id.

360 See Olson, supra note 290 (noting that Oklahoma law permits universities to provide special admits to $8 \%$ of the freshman class).

361 See Mello, supra note 301. The System includes nine campuses: UC Berkeley, UC Davis, UC Irvine, UCLA, UC Merced, UC Riverside, UC San Diego, UC San Francisco, UC Santa Barbara, and UC Santa Cruz. University of California, The Parts of UC, http://universityofcalifornia.edu/ uc-system/parts-of-uc (last visited July 24, 2020).

362 See Elisa Gatmen, Academic Exploitation: The Adverse Impact of College Athletics on the Educational Success of Minority Student-Athletes, 10 Seattle Journal for Social Justice 1, 540 (2011) (describing academic exploitation of student-athletes).
} 
assured the applicant of admission provided the student met certain minimum academic standards. ${ }^{363}$

Other universities have stricter standards when considering whether to admit applicants via special admissions process. ${ }^{364}$ A coach recruiting a prospective student-athlete who does not meet university admissions requirements likely recognizes that if the coach's university will not admit the prospect via the Special Admission exception, then another, perhaps rival, university will admit the individual. ${ }^{365}$ Thus, some universities, such as UCLA, acknowledge they are resigned to enroll special admits who excel in athletics in order to remain competitive athletically. ${ }^{366}$

Varying standards among universities could also lead athletics departments and their staff members to pressure university and admissions officials into admitting more applicants via the exception. ${ }^{367}$ This is amplified by the fact that turning down a Special Admission exception applicant who would participate in either football or men's basketball could have financial ramifications for the university, as these two sports are most likely to produce revenue. ${ }^{368}$

The NCAA espouses 16 principles that govern the conduct of college athletics. ${ }^{369}$ Every NCAA rule must advance one or more of these principles. ${ }^{370}$ One such principle is that of competitive equity, which requires the NCAA structure and programs to promote opportunity for equity in competition to ensure that individual student-athletes and universities have fair access to the benefits inherent to college athletics participation. ${ }^{371}$ However, the uneven playing field resulting from numerous different university policies regarding the Special Admission exception is counter to the NCAA's principle of competitive equity.

\footnotetext{
363 See Affidavit, supra note 14, at 928 (describing various universities’ practices regarding admissions slots for prospective student-athletes).

364 See Kiley, supra note 358 (describing widespread concern about an uneven playing field among public flagship universities with prominent athletic departments)

365 See id. (emphasizing that coaches wish to avoid having to compete against a student-athlete who the coach recruited but the university failed to admit via the Special Admission exception).

366 See Mello, supra note 301 (citing 2011 report in which UCLA officials wrote that "given UCLA's highly competitive academic reality for admitting first-year students in general, there is no real alternative ... if UCLA is to compete athletically with any success.").

367 See Kiley, supra note 358.

368 See Jeff Barker, Special Admissions Bring Colleges Top Athletes, Educational Challenges, The Baltimore Sun (Dec. 22, 2012), http://baltimoresun.com/sports/terps/bs-sp-acc-sports-special-admits-20121222-story.html. Winning, even in minor sports, can lead to increased donations, applications, and campus morale. See Olson, supra note 290

369 See Manual, supra note 32, at $\S 2$.

370 Id.

371 Id. at $\S 2.10$.
} 


\section{Lack of Educational Benefit}

Other, more philosophical arguments against the Special Admission exception for incoming student-athletes exist. Varsity Blues underscored a broad issue regarding equity and academic standards. ${ }^{372}$ At highly selective universities such as those involved in Varsity Blues, admission slots for the freshman class are scarce commodities. ${ }^{373}$ For example, over the past 15 years, applications to Ivy League universities increased $127 \%$, while the incoming class size grew by $8 \%{ }^{374}$ On a more micro level, the University of California, Berkeley, turned away 35,600 applicants for its fall 2019 freshman class, who had weighted grade point averages of 4.0 or higher. ${ }^{375}$

For every incoming student-athlete that a university admits, the university denies admission to someone else (or up to 19 other individuals per student admitted at some universities). ${ }^{376}$ Some applicants that a university turns away in favor of a student-athlete admitted via the Special Admission exception are likely more qualified academically. ${ }^{377}$ In fact, some Atlantic Coast Conference universities enrolled special admits who read at an elementary school level. ${ }^{378}$

\footnotetext{
372 See Anderson, supra note 11 (describing wide pipeline of legitimate athletic recruits into highly selective schools).

373 See Jim Jump, Ethical College Admissions: Is It Time to End Admissions Preferences for Athletes?, Inside Higher Ed (May 28, 2019), http://insidehighered.com/admissions/views/2019/05/28/ it-time-end-admissions-preferences-athletes-opinion (encouraging universities to examine whether they should give athletes admission preference). For example, in 2017, both Ivy League member Brown University and the University of Michigan had 910 varsity student-athletes. See Anderson, supra note 11. Because Brown is smaller and more exclusive, a larger share of its annual admission offers - nearly 9\% - are for prospective student-athletes whereas the athletic portion of admissions at Michigan is $2 \%$. See id.

374 See Ryan Craig, Ultimate Villain of Varsity Blues? Selfish and Shortsighted Universities, Inside Higher Ed (Feb. 28, 2020), http://insidehighered.com/views/2020/02/28/Americas-most-famous-universities-created-culture-drove-varsity-blues-scandal (espousing belief that universities' mixed-up priorities led to Varsity Blues scandal).

375 See Chris Quintana, 'How Do We Rebuild Trust?' A Year After Admissions Scandal, Presidents Say College Must Change, USA ToDAY (Mar. 10, 2020), http://usatoday.com/in-depth/news/ education/2020/03/09/college-admissions-scandal-varsity-blues-presidents/4951573002/ (providing interviews of college presidents regarding fairness of college admissions).

376 See Jump, supra note 373 (describing admission to a highly selective university as a zero-sum game).

377 See id.

378 See Barker, supra note 368 (attributing information to conference sources).
} 
As seen in Varsity Blues, the combination of scarce admission slots and universities providing admission preference for incoming student-athletes invites corruption. ${ }^{379}$

Further, questions exist pertaining to longer-term academic effects of students admitted via the Special Admission exception. At a 2012 NCAA convention, now-former U.S. Education Secretary Arne Duncan opined that too many special admits are incapable of completing both university level academic work and competing. ${ }^{380}$ A 2012 study by The Baltimore Sun revealed that when universities admit student-athletes via the Special Admission exception, they tend to not perform as well as other student-athletes in the classroom and pose unique and expensive academic challenges for their universities. ${ }^{381}$ In fact, when comparing grade-point averages, graduation rates, and retention rates of special admits with those student-athletes who satisfied their universities' regular admission requirements, the disparity was sizable. ${ }^{382}$

Thus, there is limited to no educational value in providing incoming student-athletes with Special Admissions preference. ${ }^{383}$ This leads many to conclude that admissions preferences for incoming student-athletes is the least defensible of all admission "hooks." 384

\section{E. Impropriety of College Coaches and Athletics Administrators' Involvement in Admissions Decisions and Processes}

Universities, in their drive for athletics competitiveness, have a way of creating exceptions to academic standards for incoming student-athletes. ${ }^{385}$ The

\footnotetext{
379 See Jump, supra note 373 (questioning whether the college admissions process is corrupt). Examples of the pervasiveness of use of the Special Admission exception include the University of North Carolina at Chapel Hill exempting 53 incoming football student-athletes from normal admission standards over a recent five-year period. See Kiley, supra note 358 (describing paper class scandal). In 2005, North Carolina State University admitted 23 special admit student-athletes; in 2008, the University of Illinois enrolled 88 special admit student-athletes; as of 2012, the University of Maryland averaged 26 special admits annually; and Florida State University special admits ranged between 11 and 27 in the years prior to 2012. See Barker, supra note 368. Nineteen football student-athletes were special admits at the University of Alabama between 2004 and 2006. See Associated Press, supra note 348.

380 See Barker, supra note 368 (noting that some feel that special admits should not compete in athletics their first year on campus).

${ }_{381}$ See id. (describing results of interviews and document review that included universities such as the University of Maryland, North Carolina State, and Georgia Tech University).

382 See id. One legal scholar opines that special admissions contribute to academic exploitation of student-athletes. See Gatmen, supra note 362, at 542.

383 See Jump, supra note 373 (arguing against sentiment that the playing field is a classroom).

384 See id. (defending admission preferences for underrepresented populations and legacy admissions).
}

385 See Thomason, supra note 17 (describing special admissions process at Stanford University). 
Special Admission exception is ingrained in modern ultracompetitive college athletics, especially in the sports of football and men's basketball. ${ }^{386}$ In fact, the aforementioned Gurney describes special admissions as college athletics's "original sin." 387

For example, according to Gurney, college coaches can become de facto admissions directors when they want an applicant admitted. ${ }^{388} \mathrm{~A}$ plug from a coach or athletics administrator for an applicant who may not otherwise meet admission requirements can serve as a weighty thumb on the scale or even the decisive word at universities where most other applicants earned stellar grades and test scores. ${ }^{389}$ Singer's scheme exploited this weak spot in the university admissions process - the ability of college coaches and athletics administrators to virtually guarantee admission. ${ }^{390}$ Varsity Blues shined a spotlight on the connections between coaches and university gatekeepers. ${ }^{391}$

\section{Conclusion}

Varsity Blues exploited a cavernous hole in university admissions in a scheme that took place undetected by university officials over eight years. It was happenstance that federal authorities learned of the scheme when pursuing another matter. The resulting criminal prosecutions of Heinel and coaches have yielded relatively light punishments, and civil lawsuits against the involved universities have been unsuccessful. The NCAA infractions process in another admissions fraud case yielded penalties, but the coach who secured side door admission for an applicant was still able to obtain desirable employment with the Boston Celtics. With numerous coaches making hundreds of thousands of dollars from Varsity Blues, a coach conducting a risk-reward analysis may still consider participating in a

\footnotetext{
${ }_{386}$ See Barker, supra note 368 (detailing results of survey of select schools with special admissions criteria).

387 See Olson, supra note 290 (stating that special admits have been accepted in college football and basketball since college athletics' birth).

388 See Olson, supra note 290 (quoting Gurney as referring to college athletics as the "weak link" in higher education).

389 See Anderson, supra note 11 (stating that athletic talent can help applicants stand out at selective schools); see also Thomason, supra note 17 (noting that a coach's designation of an applicant as a recruited prospective student-athlete can guarantee the applicant's admission at some universities while at others it provides a leg up in the process).

390 See Thomason, supra note 1 (noting that Singer's clients sought admission guarantees from Singer and Singer used coaches to deliver them).

391 See Anderson, supra note 9 (describing athletics as a powerful and pervasive role in admission to prestigious universities); see also Elizabeth Vulaj, Endownment or Inducement? The Legal Distinction Between College Donations and Bribes, 91 Ост. N.Y. Sт. B.J. 46, 48 (Oct. 2019) (explaining differences between legal definition of bribe and a lawful donation).
} 
future similar scheme. California attempted to address admissions fraud such as that which occurred in Varsity Blues through legislation but stopped short of what could have been an effective reform package. Universities are left to devote resources to new policies and procedures designed to mitigate the likelihood of a future admissions scandal.

With the potential for corruption, civil lawsuits, NCAA penalties, having to comply with new state legislation, needing to devote resources to new admissions procedures, and embarrassment associated with Varsity Blues involvement, there are numerous reasons that universities and states should eliminate, alter, or reduce use of the exception. Further, research highlights a lack of educational benefit when universities admit students via the Special Admission exception. However, due to its current widespread use to admit incoming student-athletes, individual universities are unlikely to eliminate or reduce use of the exception and incur any resulting competitive disadvantage unless their athletics competitors follow suit. Thus, NCAA-wide reform through legislation reducing, altering, or eliminating use of the Special Admission exception would be more effective. Any such changes to the Special Admission exception would provide consistency with other NCAA legislation and principles, and eliminate many potential headaches for universities.

Another option would be for the NCAA to require member universities who admit incoming student-athletes via the exception to do so at a rate equal or substantially proportionate to use of the exception for admitting incoming non-athlete students. This would eliminate concerns regarding inconsistency with NCAA extra benefits and recruiting legislation, as use of the exception for incoming student-athletes would be consistent with its use for incoming non-athlete students.

Alternatively, individual universities and states should consider using the Special Admissions exception only for applicants who meet criteria unrelated to athletics or family wealth such as state residency and/or first-generation university attendance. Doing so would help accomplish the worthwhile goals that Newsom and Ting articulated with respect to California's College Admissions Reform package and eliminate or reduce the perpetuation of the inequities that accompany special admissions solely based on an applicant's socioeconomic status and/or athletic ability. 